\title{
The Dimensions of Finance Researches in Bangladesh: 1973-2006
}

\author{
Md. Abu Rashed \\ Sr. Consultant, Project Development \\ Infrastructure Investment Facilitation Center (IIFC) \\ An enterprise of Economic Relations Division (ERD) \\ Ministry of Finance, Government of Bangladesh \\ Dhaka, Bangladesh \\ E-mail: arashed@infra-bd.com \\ Md. Mahmudul Alam \\ $\mathrm{PhD}$ Researcher \\ Institute for Environment and Development (LESTARI) \\ National University of Malaysia (UKM), Malaysia; \\ E-mail: rony000@gmail.com
}

\section{Citation Reference:}

Rashed, M.A., and Alam, M.M. 2011. The Dimensions of Finance Researches in Bangladesh: 1973-2006, Elixir Online Journal: Elixir Finance, Vol. 33, pp. 2138-2159. Available at

http://elixirjournal.org/user articles/1301640033 33\%20(2011)\%202138-2159.pdf>

This is a pre-publication copy.

The published article is copyrighted by the publisher of the journal. 


\title{
The Dimensions of Financial Researches in Bangladesh: 1973-2006
}

\author{
Md. Abu Rashed, Md. Mahmudul Alam
}

\begin{abstract}
The role of growing financial sectors is already marked with good attention of the policy makers, investors, academicians and researchers in Bangladesh. To accelerate and sustain the economic growth, the dimension of finance research is very critical which subsequently results diversified types of researches being conducted continuously in this area. At the same time, assessing the directions of researches is also very important to find out the gap in the research vicinity and to explore uncovered issues keeping in mind that the world of finance is vast and there is little success in Bangladesh in terms of area wise research conducted. Moreover, the financial crisis of the world allows us to think further and look back on the finance researches being conducted and its evolution. This paper is an attempt to analyze the dimensions of financial researches that published in Bangladesh from 1973 to 2006. This study analyzes 549 papers covering from available issues (612 issues out of 750) of 18 journals published by well reputed academic institutions in Bangladesh. This paper categorizes the existing finance publications into different major areas and sub-areas. The category of finance researches is also segmented in three time periods based on the research trend in three decades. Finally the paper highlights the most focused areas and its outcomes, where most of the researches have been conducted but still need to do further study, and unexplored areas, where research works is highly required. This paper will be helpful for the financial institutions, researchers and policy makers.
\end{abstract}

Key Words: Research; Finance; Publications; Academic journal; Bangladesh

\section{INTRODUCTION}

Finance studies address the ways in which individuals, businesses and organizations raise, allocate and use monetary resources over time. The term finance may thus incorporate any of the following: the study of money and other assets, the management of those assets, profiling and managing project risks, and so on. Finance is an interesting, complex, and dynamic field that affects all areas of business and many areas of personal life. Internet trading, the globalization of capital markets, the deregulation of the banking industry, and the evolution of derivative assets have created a wide array of opportunities for finance areas. Moreover, worldwide repetitive financial crisis encourage researchers to concentrate this sector further.

Finance is a huge area where many academic and professional researches have been performed. Finance has multiple areas that can further divided to several sub-sectors. All the sub-areas are interconnected and related to other discipline. This paper is an attempt to complete and categorize of existing academic finance research in Bangladesh. In addition, this study analyses previous finance research papers to provide guidelines for the finance researchers as well as to identify or explore the research density and associated areas and the general findings associated. At the same time, this will find out the gap in finance research that will provide guideline in future financial researchers of Bangladesh. 


\section{METHODOLOGY}

For this study, it covers 18 finance relevant journals that are published within the country. From 1973 to 2006, total 750 volumes of these journals were published. This study covers all available volume, 612 volumes, which is over $80 \%$ of all published volumes. In these volumes a total of 549 papers were found relevant to finance field. There are another three journals published from department of management and marketing of Dhaka University and journal from Chittagong University, which are not covered in this study (Table 1). There are some other researches that include professional or consulting research, which have not been considered in this paper. Only the papers published in Bangladesh have been selected. However, research for macroeconomics is also excluded here.

$<$ Table 1>

Upon collection, data has been sorted out according to the subject areas of the papers. Then it aims to find out the major, minor and untouched areas on which the previous finance researches had been conducted. After the sorting, a common summary of findings from the existing research papers has been prepared. At the same time this paper also finds out the significant gap and findings in different areas of finance researches in Bangladesh. This paper works as a collection of all past researches that provides a guideline for further researches.

\section{TREND OF FINANCIAL RESEARCHES}

Publisher wise trend: Among the covered 18 journal, the publishers of 10 are from public university, 4 from private university and other 4 are from different institutions. Except the University of Dhaka, other university journals are not focused on finance relevant publications, where institutional publications are more concentrated on finance related publications (Table 2).

\section{$<$ Table 2>}

Year and period wise research trend: To understand the focused area of finance research, this study has divided the time period in three decades: early trends from 1976 to 1986, intermediate trends from 1987 to1996, and modern trends from 1997 to 2006 . After liberation, there was no publication on relevant issues up to year 1975. In overall, the trend of research on finance areas is increasing (Table 3). The trend is relatively high in recent years, that indicate the research on different areas of finance is obtaining more attention from the researchers.

\section{$<$ Table 3>}

In the early trends, a total number of 98 papers have been found, 155 in the intermediate trends and 296 in the modern trends. The numbers of papers have almost doubled in every following period. The banking sector dominates in all three trends consecutively, and the capital market is highly focused in recent years (Table 4). Some of the sectors are explored very little such as, dividend policy, money market and valuation \& pricing theories. 
i. Early Trends (1976 to 1986): In the early trends banking sector was emphasized largely, with 30 papers, which is almost double than the area of financial planning \& analysis - the next place holder with 17 papers. The least number of papers were published in insurance \& risk management, and money market area with only 1 paper. In this decade, capital market and capital structure was explored little and no works on dividend policy \& decision, valuation \& pricing theory, and other miscellaneous areas.

ii. Intermediate Trends (1987 to1996): In the intermediate trends, total number of papers increased more than $50 \%$ from early trend. In this period, the banking sector again received highest emphasizes. Due to stock market crash in 1996, capital market received a good attention as well as financial planning \& analysis, and financing \& capital structure, but investment decision $\&$ analysis, valuation $\&$ pricing theories were almost out focused. Moreover, dividend policy \& decision, and money market was still unexplored with only 1 paper each.

iii. Modern Trends (1997 to 2006): In the modern trends the numbers of papers have increased 100\% more than that of the intermediate trend. After the stock market crash, huge attention was given in capital market and corporate finance, and financing \& capital structure. As usual, money market, dividend policy \& decision were very little focused. Interestingly in the recent period, the earlier research focus on working capital management, have been reduced significantly.

Area wise research trend and gap: Relevant publications of finance papers are differentiated according to areas and sub areas in Table 5. Those are categorized in 12 different major areas that includes banking, capital market, corporate finance, dividend policy and decision, financial planning \& analysis, financing and capital structure, insurance \& risk management, investment decision and analysis, money market, valuation \& pricing theories, working capital management and few other miscellaneous area.

\section{$<$ Table 5>}

From the banking category, the most explored sub-areas are performance evaluation, loan \& credit, financial sector reform, banking policies and role of banks. There are still many unexplored areas such as, e-banking, savings analysis, bank management and ethical issues. From the capital market, highly covered sub-areas are market development, initial public offering, market efficiency, stock index, and share valuation/price. Here many areas are still unexplored such as, book building system, central depository system, mutual funds, stock return, wealth management, and few areas are even untouched at all such as, capital market equilibrium, internal capital market, stock split, etc.

From corporate finance area, most emphasized sub areas are corporate governance, industrial financing, and investment. The less explored sub-areas are acquisition, corporate earnings, determinants, exchange rate, executive compensation, and MNCs. The uncovered sub-areas are balance of payment, corporate restructuring, currency future, joint venture, licensing, and merger. Dividend itself dominates in dividend policy and decision sub-area, where others sub-areas - share re-purchase, signaling effect, and warrant - are almost unexplored. 
Financial analysis, performance evaluation, budgeting, and comparative analysis dominate among the financial planning $\&$ analysis sub-areas. Here very few studies done on economic value addition, financial forecasting, linear programming, liquidity/ cash management, marketable securities, and return on equity. Other few areas are fully out of research such as, financial modeling, growth modeling, receivables, return on investment, shareholder equity planning, and social responsibilities.

Lease financing, comparative analysis, financial sector reform leads in the sub-areas of financing and capital structure. Here few studies done on financial distress/ bankruptcy, human capital, leverage, cost of capital, and development, and no research yet conducted on entrepreneur, long term financing and private placement. Both insurance and risk management are focused under the area of insurance \& risk management, but hedging and trends \& patterns of insurance got very little attention.

There are researches in all the sub-areas of investment decision and analysis, except the hurdle rate. Here capital investment, portfolio management, and capital budgeting were most focused areas, but very little works are on depreciation, tax, interest rate, and symmetric $\&$ asymmetric information. In overall, money market area is the very ignored one where no research has been conducted on deposit account and money market fund, and very few are on call money rate, money market and money market instrument.

Only the research on CAPM dominates from the valuation \& pricing theories subareas. Very few researches are conducted on the sub-area of cost of capital, determinants, Gordon model, stock pricing, risk management, return on investment, and comparative analysis. Here maximum numbers of completely unexplored areas exist such as, agency cost, bond pricing, bond return, break-even analysis, comparison, corporate tax, earning per share analysis, leverage, management, option valuation, and security portfolio.

From the area of working capital management, issues like theory \& practices were mostly emphasized areas including inventory management and liquidity management. Few studies were conducted on Miller theorem, receivable, cash flow estimation, but no work on credit policies, marketable securities and trade credit financing. There are also very few researches on miscellaneous finance areas, such as two papers on purchasing power parity from international finance, and one from non-financial factor.

\section{FINDINGS AND FOCUSES OF EXISTING RESEARCHES}

Here in this paper, a brief overview of general findings for most important areas of finance researches has been provided. The banking researches find the trend of the development of the banking system, bank credit and its limitation in Bangladesh. There were observations that the rural credits performance being satisfactory, but still playing good role in the rural development of this country. The financial organizations both government and private should play more vital role in this regard and also in financial reform in Bangladesh. However, other loans in different sectors are also following the under performance trend over years including defaulting loan performance. In many of the researches in banking sectors the authors tried to evaluate the performance analysis between NCBs and PCBs and showed that private commercial banks are more efficient in capital and other financial managements. This is due to excessive government interventions, absence of prudential and information regulations, excessive implementation of economic regulations etc. However some special types of the 
banks are performing better like the Krishi (Agricultural) Bank, Islamic Bank and Grameen Bank in rural areas.

Countries like Bangladesh depend heavily on the development of security markets for the growth of the capital market. It has been evident through few researches that Dhaka Stock Exchange is efficient in weak form sense, but many disagree. There are numbers of papers on the share valuation, IPO's, price movement and stock return determining methodology. After 1996 tragedy, more focuses were given on trading rules and protection of small investors' interest. There are recommendations in many papers for strengthening the capital market of Bangladesh. Capital Market is subject to government regulation. So the Government along with the ICB should formulate strategies for selective control of the capital market.

In the corporate finance sector, the researchers have talked about the exchanges rate and performance of public and private enterprises in Bangladesh. There are number of studies regarding the sectoral performance by different industrial and agricultural sectors in Bangladesh. There were attempts to provide overviews on agency problems and the role of corporate governance in managing the corporate financial issues. There is also evidence that the mutual funds in Bangladesh is not performing very well. The regulatory agencies like, SEC, stock exchanges, Chamber of commerce, etc. should participate along with ICAB in the reviewing of the accounting standards to the requirement of Bangladesh. There are various constraints that hinder the development of SMEs in Bangladesh, such as lack of medium to long-term credit, limited access to market opportunities, technology, and expertise and business information. Lack of suitable incentives, inefficient and limited services from relevant government agencies as well as poor capacity of entrepreneurs are other reasons for the slow growth of SMEs. Financial liberalization is crucial for efficient financial performance. That means allowing the financial variables like interest rates, discount rates, exchange rates, and other pricing rates for using of money to be determined through market forces.

Financial analysis of past operations on the basis of financial statements is thus important for an existing as well as for intending investors. So it is to the management concern for the purpose of internal financial management and control. Budgeting is a vital part of financial planning. If a business faithfully applies the method of budgeting to plan and control its operations, one might assume that it would not need to undertake a separate program to reduce costs or improve profits. A systematic analysis of financial statements of a borrowing company can provide the banker with meaningful guide regarding decision. But unfortunately, modern techniques of analysis and interpretation of financial statements are not widely used in commercial banks. For development efforts in any country, resources need to be raised from internal or external sources. It may be said that success of the enterprise has been attributed to adherence of financial management principles and techniques in their perspectives. There are strong evidence that the industrial sector of Bangladesh have suffered a lot due to poor financial planning and analysis especially in small-scale industries in Bangladesh.

In Bangladesh financing and capital structure was largely dominated by small scale industries. But over the periods, this situation is changing. Regarding the financial structure of joint companies in Bangladesh, it concerns the high debt holding of the companies. The capital Structure has no significant impact on the firm's profitability, dividend payout patterns and market value of share. There are researches on financing techniques and options like lease financing, house financing etc. Venture capital financing is one of the most dominating 
factors in worldwide entrepreneurial development. Venture capital has emerged as an important area of finance for academic researchers for the last 15 years or more. Towards development of an economy, financial intermediation in the economy is fundamental. This causality has been presented in various papers in the literature.

\section{CONCLUSIONS}

This paper has counted and incorporated the articles or papers on finance related issues which were published in the local journals in Bangladesh. Past three decades of finance research in Bangladesh shows the number of researches has almost doubled in every following period. Here, a number of researches have been performed, but there are still huge gap in researches among different finance areas. The banking sector has received more focuses by researchers based on its contribution in the economy, or due to more focuses on banking sector, it performs better contribution in the economy. Recently capital market and relevant issues have also received good focuses as a consequence of the role of stock exchange being crucial for Bangladesh economy.

It has also been found that concentration has been made on few particular areas whereas there are many areas which are completely uncovered. Money market tools and long term financing are very important issues for the development of Bangladesh economy in the coming days. Moreover, real estate is now going to become a very important sector. Researchers should be more focused in these areas.

Finance is a vast area for conducting research works. This paper is also expected to help the future prospective researchers to choose their desired field of study where scopes and potentialities are available. It can be believed that this study may have a good possibility to be viewed as a collection of almost the maximum numbers of academic finance researches being conducted in Bangladesh. Moreover, there is a significant scope for future study to cover the academic finance researches which have been published in overseas journals and that would definitely make a significant advanced step for this study.

\section{BIBLIOGRAPHY}

1. Abdullah, A. S. M, Bhuiyan, Md. Nazimuddin. (1994). A Decade of "Islami Banking" In Bangladesh: An Insight into operation and Result(s). The Cost \& Management Journal. 22(4) (July - August), 19-24.

2. Abdullah, A. S. M. (1979-1980). Ratio Analysis in Financial Statement. The Bangladesh Accountant, 3(6 \& 7) (October-March), 5-8.

3. Abdullah, A. S. M. (1980). Inventory Management. The Bangladesh Accountant, 3(8) (April-June), 41-43.

4. Abdullah, Milan Mumtaz. (2003). Ground realities of corporate governance. The Bangladesh Accountant, 39(12) (January - March), 37-42.

5. Abdullah, Shahnaz \& Bannerji, Prashanta K. (1999). Financial Spread Sheet: A New Approach to Financial Statement Analysis. The Dhaka University Journal of Business Studies, 20(1) (June), 209-232.

6. Abedin, M. Zainul. (1988). Industrial Development in Bangladesh: Role of Public and Private Sectors. Bank Parikrama, 13 (3 \& 1).

7. Adhikary, Bishnu Kumar. (2001). The Status of Venture Capital Financing in Bangladesh: A Case Study of Grameen Fund. Bank Parikrama, 26(2) (June). 
8. Adhikary, Bishnu Kumar. (2003). Loan Classification and Provisioning of Banking Sector. Journal of the Institute of Bankers, Bangladesh. 50. (June).

9. Admas, Carol \& Zutshi, Ambika. (2006). Corporate Social Responsibility: Why Business Should Act Responsibly and Be Accountable. The Cost \& Management Journal, 34(4) (July - August), 5-17.

10. Ahmad, S. (1987). Saving Mobilization and Financial institutions in Bangladesh. Bank Parikrama, 12(2) (June).

11. Ahmad, W \& Murshed, A. J. M. H. (2000). East Asian Financial Crisis: Lessons for the Developing Countries. The Dhaka University Journal of Business Studies, 21(2) (December), 97-117.

12. Ahmad. S., Islam, Mohammad S. \& Uddin, Muhammad M. (2002). The Operating Performance of Firms Conducting Seasoned Equity offerings in Bangladesh. Journal of Business Studies, 23(2) (December), 205-217.

13. Ahmed, A. K. M. U, Khan, Harun-ar-Rashid \& Latif, E. (1993). Foreign Banks in Bangladesh: Performance \& Limitation. The Dhaka University Journal of Business Studies, 14(1) (June), 185-198.

14. Ahmed, A. K. N. (1996). Capital Market in Bangladesh. Journal of the Institute of Bankers, Bangladesh. 43. (June), 1-9.

15. Ahmed, Abu. (1992). Bangladesh Stock Market: Investors are indignant at irregularities and Government Inaction. Bank Parikrama, 17(1).

16. Ahmed, Abu. (1992). Financial Liberalization in Bangladesh: Components, impediments and Impact. Bank Parikrama, 17.

17. Ahmed, Abu. (1993). Bangladesh Bank's BCD Circular No. 34 and its impact on Bank's Profit. Bank Parikrama, 18 (1 \& 2).

18. Ahmed, Abu. (1993). Financial Sector Reform: The Interest Rates Aspects. Bank Parikrama. 17 (3 \& 4) (September \& December).

19. Ahmed, Abu. (1994). Capital Market in Bangladesh: The Required Reform Dimensions. Bank Parikrama, 19(3 \& 4) (September \& December).

20. Ahmed, Akamuddin. (1984). Islamic Banking - Evolution or Revolution. The Cost \& Management Journal. 12(5) (September - October), 33-36.

21. Ahmed, Anwar U. (1987). A study of nonrepayment of short-term aggricultural loans in Bangladesh. Journal of the Institute of Bankers, Bangladesh. 26. (December), 1-20.

22. Ahmed, Anwaruddin, Chowdhury, A. K. M Nurul Alam. (1983). Impact of a Swanirvar credit scheme on income and employment among the poor women in rural Bangladesh. Journal of the Institute of Bankers, Bangladesh. 18. (December), 18-27.

23. Ahmed, Farid M \& Mina, M. S. (1982), Tea Industry and its Financing. The Dhaka University Journal of Business Studies, 3(1) (June), 97-110.

24. Ahmed, Farid U. \& Howlader, Sushil R. (1988) Effects of Development of the Banking System on the saving Behaviour - A Case Study. The Dhaka University Journal of Business Studies, 9(2) (December), 63-82.

25. Ahmed, Farid. (1990-1991). Mean-Variance Approach in Portfolio Choice: A Theoretical Analysis. Journal of the Institute of Bankers, Bangladesh. 31, 32 \& 33. (June - December), 16-32.

26. Ahmed, Faruqquddin. (1979). Money Market in Bangladesh. Journal of the Institute of Bankers, Bangladesh. 9. (June), 16-27.

27. Ahmed, Faruquddin 1990-91. Nationalized Commercial Banks in Bangladesh - An Analysis of their operational and Functional performances. Bank Parikrama. $15 \& 16,77-84$. 
28. Ahmed, Faruquddin. (1976). Export Credit Insurance in Bangladesh. Journal of the Institute of Bankers, Bangladesh. 4. (December), 22-27.

29. Ahmed, Faruquddin. (1981). Exchange Rate system in Bangladesh. Bank Parikrama, $6(1 \& 2)$, (March \& June).

30. Ahmed, Faruquddin. (1982). Inflation in Bangladesh: The Current Situation. Journal of the Institute of Bankers, Bangladesh. 16. (December), 45-53.

31. Ahmed, Faruquddin. (1984). Islamic Banks: Some Thoughts on their Promotion and Control. Bank Parikrama, 9(3 \& 4) (September \& December).

32. Ahmed, Faruquddin. (1994). Money Market in Bangladesh. Bank Parikrama, 19(3 \& 4) (September \& December).

33. Ahmed, Jamal Uddin. (1988). Financing Strategy of Foreign Partners in the joint Venture Companies in Bangladesh. The Dhaka University Journal of Business Studies, 9(1) (June), 15-29.

34. Ahmed, Jamal Uddin. (1988). Problems of Rural Loan Utilisation: A Study of two selected area. Journal of the Institute of Bankers, Bangladesh. 27. (June), 4050 .

35. Ahmed, Kamran. (1981). The Role of Bangladesh Shilpa Bank in Financing Private Sector Industries. The Dhaka University Journal of Business Studies, 2(2) ((December), 95-107.

36. Ahmed, M, F. (1988). Implications of Portfolio Theory and Capital asset pricing Model (CAPM) for the provision of accounting Information with Special Reference of Bangladesh. The Dhaka University Journal of Business Studies, 9(2) (December), 105-119.

37. Ahmed, M. (1986). Profit Performance of Rural branches of the National Banks. The Dhaka University Journal of Business Studies, 7(2) (December), 19-26.

38. Ahmed, M. F. (1983). Working Capital Management in Jute Industries. The Dhaka University Journal of Business Studies, 4(1) (June), 91-102.

39. Ahmed, M. F. (1990). Aspects of Capital Market Development in Japan and its Relevance to Bangladesh. The Dhaka University Journal of Business Studies, 11(2) (December), 85-100.

40. Ahmed, M. F. (1990). Capital Asset Pricing Model (CAPM): Some Empirical Evidence from a Developing Economy. The Dhaka University Journal of Business Studies, 11(1) (June), 63-77.

41. Ahmed, M. F. (1991). Dividend Policy: A study of Enterprises Registered with the Dhaka Stock Exchange (DSE). The Dhaka University Journal of Business Studies, 12(2) (December), 107-120.

42. Ahmed, M. F. (1993). Seasonal and size Anomalies in Stock Market: Empirical Evidence from Japanese Market. The Dhaka University Journal of Business Studies, 14(2) (December), 81-97.

43. Ahmed, M. F. Chowdhury, A. A. M. U. (1992). House Building Financing by BHBFC: Some Relevant Issues for Borrowers. The Dhaka University Journal of Business Studies, 13(1) (June), 161-174.

44. Ahmed, M. Farid, Chowdhury, A. A. \& Mahboob Uddin. (1987). Role of the main Bank System in Financing Japanese Firms. The Dhaka University Journal of Business Studies, 8(2) (December), 161-174.

45. Ahmed, M. Farid, Hassan, Syed Rashidul. (1991). An Analysis of cost of capital estimation with special reference to Bangladesh. The Cost \& Management Journal. 19(2) (March- April), 12-16. 
46. Ahmed, M. Farid. (1988- 1989). Implication of Interlocking Stockholding in Japanese Business. Group its relevance to Bangladesh. Journal of the Institute of Bankers, Bangladesh. 28, 19 \& 30. December - June - December. 104-127.

47. Ahmed, M. Farid. (1990-1991). On Bank's Role in shaping the capital Market in Japan and its Relevance to Bangladesh. Bank Parikrama, 15 \& 16.

48. Ahmed, Mahbub, Sarker, Md. Maksudur Rahman. (1993). Defaulter pattern and its impact on profit performance of commercial banks in Bangladesh: Case Studies. The Cost \& Management Journal. 21(1) (January - February), 13-19.

49. Ahmed, Mahbub. (1986). An Evaluation of the Incentive Systems in the Nationalized Commercial Banks. The Cost \& Management Journal. 14(5) (SeptemberOctober), 39-42.

50. Ahmed, Mahmood. (1986). Interest or Profits as a cost of Bank Fund: An analysis for Entrepreneur. Bank Parikrama, 11(3 \& 4) (September \& December).

51. Ahmed, Mahmood. (1988). The Success of Islamic Bank. Bank Parikrama, 13 (3-4).

52. Ahmed, Mamtaz Uddin \& Yusuf, Mohammad Abu. (2005). Corporate Governance: Bangladesh Perspective. The Cost \& Management Journal, 33(6) (NovemberDecember), 18-26.

53. Ahmed, Mamtaz Uddin, Firozzaman, Md, Islam, Md. Ainul. (1995). Political Risk Assessment. The Bangladesh Accountant, 23(1) (January- March), 50-53.

54. Ahmed, Mamtaz Uddin, Firozzaman, Md. (1994). Cost-Volume-Profit Analysis Mathematical Approach to Determine Suitable Combination of Business Activity. The Cost \& Management Journal. 22(6) (November-December), 3437.

55. Ahmed, Mamtaz Uddin, Moniruzzaman, Mir. (1994). Capital Budgeting and Automation - The Questionable Reliability of Traditional Capital Budgeting Techniques. The Cost \& Management Journal. 22(3) (May - June), 13-20.

56. Ahmed, Mujib U. \& Karim, Khondkar E. (1992). Stock Market Reaction with Pronouncement of SFAS 95-the Statement of Cash Flow: A U. S Experience. The Dhaka University Journal of Business Studies, 13(1) (June), 125-139.

57. Ahmed, Muzaffar. (1982). Cost Reduction by Value Analysis. The Cost \& Management Journal. 10(4) (October-December), 14-20.

58. Ahmed, Muzaffar. (1983). Budget - A Comprehensive and Coordinated Plan of Operations. The Cost \& Management Journal. 11(2) (March - April), 19-24.

59. Ahmed, Nasir Uddin. (1997). Role of ICB in Developing the Capital Market of Bangladesh. The Cost \& Management Journal. 25(5) (September - October), 18-24.

60. Ahmed, S. k. (1978). Bank Credit and Law of Limitation. Bank Parikrama, 3(1) (March), 37-45.

61. Ahmed, Sabbir. (2000). Bank Loans Accounting Provision for loan losses and other Related Issues. The Bangladesh Accountant, 30(3) (July - September), 28-38.

62. Ahmed, Sabbir. (2000). Banks in Asia - An Analysis of Post Economic crisis period. The Bangladesh Accountant, 31(4) (October - (December), 63-66.

63. Ahmed, Shahid Uddin. (1987). Attitudes in Rural Areas towards a Particular Insurance Scheme: An Empirical Study. The Dhaka University Journal of Business Studies, 8(2) (December), 175-184.

64. Ahmed, Shaikh S, Iqbal, Md. F. \& Khalily, M. A. B. (1994). Should the Industrial Development Banks be restructured in Bangladesh Financial Market? The Dhaka University Journal of Business Studies, 15(1) (June), 77-94. 
65. Ahmed, Shaikh S. \& Chowdhury, Mohammad J. A. (2002). Rural Poor and the Financial Institutions in Developing Countries. Journal of Business Studies, 23(2) (December), 335-340.

66. Ahmed, Shaikh S. \& Chowdhury. (2003). Theoretical Overview of Finance and Development in Developing Countries. Journal of Business Studies, 23(1) (June), 25-30.

67. Ahmed, Shaikh S., Ahsan, A. \& Azam, Mohammad N. (2003). Share Price Behavior after earning announcement at Dhaka Stock Exchange. Journal of Business Studies, 24(1) (June), 171-182.

68. Ahmed, Shaikh S., Chowdhury, Mohammad J. A \& Imam, Mahmood O. (2002). Determinant of Accessibility of SSEs to Formal credit in Bangladesh. Journal of Business Studies, 23(2) (December), 175-190.

69. Ahmed, Shanker. (1992). Rural Credit and its Dependency on Farm Size. The Cost \& Management Journal. 20(2) (March-April), 33-36.

70. Ahmed, Sultan, Uddin, Md. Salim. (1994). Adequacy of Bank's Capital: A Study on NCBs. The Cost \& Management Journal. 22(5) (September - October), 26-28.

71. Ahmed, Sultan, Uddin, Md. Salim. (1996). Performance of Bangladesh Shilpa Bank: An Evaluation. The Cost \& Management Journal. 24. (5) (September October), 18-24.

72. Ahmed, Syed Ihtiaq. (1992). Banking Policies and Economic Development. The Bangladesh Accountant, 20(4) (October - December), 58-61.

73. Ahmed, Z. U., Bhuiyan, Md. H. U \& Islam, Muhammad A. (1999). Southeast Asian Financial Crisis: Lessons for the LDCs. The Dhaka University Journal of Business Studies. 20(2) (December), 137-152.

74. Ahsan, Amirul \& Bashar, Omar Khaled Mohammad Rizwanul. (1999). Security Price Reaction to Dividend Announcement: Evidence from Dhaka Stock Exchange Ltd. Bank Parikrama, 24(3 \& 4) (September \& December).

75. Ahsan, M. Kismatul, Rahman, M. Zillur. (2003-2004). Growth of stock markets: The scenario of south Asian Countries. The Bangladesh Accountant, 42(15) (October-March), 114-119.

76. Akan, Md. Habibur Rahman. (1989). The Role of Cost Accounting and Cost Accountant in Cost Control. The Cost \& Management Journal. 17(6) (November-December), 26-30.

77. Akan, Md. Habibur Rahman. (1998). Capital Budgeting: Key Elements in Selecting a project. The Bangladesh Accountant, 26(2) (April - (June), 134-137.

78. Akan, Md. Habibur Rahman. (1998). Inventory Planning and Control: A Conceptual Analysis. The Bangladesh Accountant, 26(3) (July - September), 97-101

79. Akhtaruzzaman, Md., Akhtar, Mahfuza \& Masuduzzaman, Mohammad. (2005). Recent Fluctuations in Call Money Rate: Causes and its Impact. Bank Parikrama, 30(1) (March).

80. Akhter, Selim \& Chowdhury, S. S. H. (1996). Price Behavior of Common Stock New Issues: Evidence from an Engineering Equity Market. Journal of Business Administration, 23(3 \& 4) (July \& (October).

81. Akkas, Md. Ali. (1999). Social Responsibilities of Business: The Bangladesh Perspective. The Cost \& Management Journal, 27(4) (July - August), 14-20.

82. Al Masum, M., Anwar, Adina N. \& Chowdhury, A. A. (1998). Performance of Foreign Baks VIS-À-VIS other Commercial Banks Operating in Bangladesh. The Dhaka University Journal of Business Studies, 19(2) (December), 203-213. 
83. Alam, A. H. M. Mahbubul. (1988-1989). Financial System \& Economic Development. Journal of the Institute of Bankers, Bangladesh. 28, 19 \& 30(December - June - December), 59-81.

84. Alam, A. K. M Sahabub. (1988). Creative Accounting: Is it leading us towards a Stock Market Crash. The Cost \& Management Journal. 16(5) (September - October), 5-7.

85. Alam, AKM Sahabub. (1988). Finance Act, 1988 - Contradictions and Controversies. The Cost \& Management Journal. 16(4) (July - August), 5-6.

86. Alam, AKM Sahabub. (1990). Changes In Securities Regulations: One Step Forward or One Step Backward?. The Cost \& Management Journal. 18(4) (July-August), 20-22.

87. Alam, Jahangir. (1984). Income From Money Lending and The rural Credit Market: The effect of village organization. Bank Parikrama, 9(3 \& 4) (September \& December).

88. Alam, Jahangir. (1996-1997). Restructing of Bank in Bangladesh. Journal of the Institute of Bankers, Bangladesh. 44 \& 45. (December - June), 67-79.

89. Alam, Khorshed. (1994). Reforms in Finance and Banking in Bangladesh. Bank Parikrama, 19(3 \& 4) (September \& December).

90. Alam, Khurshid. (1992). Capital Market and Privatization - A New Horizon of Expanding Equity in the Development of Bangladesh. Bank Parikrama, 17.

91. Alam, Md. Jahangir \& Ahmad, Mahijabeen. (2001). DSS Models for Lending Decisions: Case Study of Commercial Banks in Bangladesh. Journal of Business Administration, 27(3 \& 4) (July \& October).

92. Alam, Md. Jahangir \& Rahman, Narur. (2002). Model for Determining Creditworthiness of Loan Applicants in Commercial Banks in Bangladesh. Journal of Business Administration, 28 (1 \& 2) (January \& April).

93. Alam, Md. Jahangir \& Rahman, Nurur. (2005). Empirical Investigation ion Loan Repayment Performance Evidence from Nationalized Commercial banks in Bangladesh. Journal of Business Administration, 31(1 \& 2) (January \& April).

94. Alam, Md. Jahangir \& Uddin, Md. Hamid. (2003). Impact of Socio Economic and Political Factors on Loan Repayments in Nationalized Commercial Banks of Bangladesh. Journal of Business Administration, 29(3 \& 4) (July \& October).

95. Alam, Md. Jhangir, Uddin, Md. Hamid \& Sogra, Khair Jahan. (2005). Managers' Background and the Financial Performance: An Empirical Study on the companies Listed in Dhaka Stock Exchange. Journal of Business Administration, 31(3 \& 4) (July \& October), 43-50.

96. Alam, Md. Nurul \& Jahan, Sayeeda Bilquis. (1996). Impacts of Stock Market Debacle in 1996 on National Economy of Bangladesh. Bank Parikrama, 21(3 \& 4) (September \& December).

97. Alam, Md. Shamsul \& Ullah, Md. Anwar. (2006). SMEs in Bangladesh and Their Financing: An Analysis and Some Recommendations. The Cost \& Management Journal, 34(3) (May - June), 57-72.

98. Al-Amin, Hossain, Mahboob, Dewan. (2003-2004). Economic Value Addition: From Stakeholder's point of view. The Bangladesh Accountant, 42(15) (OctoberMarch), 106-108.

99. Ali, Abed. (1991-1992). Indicators of Monetary Policy with special reference to Bangladesh. Journal of the Institute of Bankers, Bangladesh. 34 \& 35 . (December - June), 66-75. 
100. Ali, M. Shah Nawaz. (1990). Management of Capital Structure of Rajshahi Jute Mills: A Case Study. The Cost \& Management Journal, 18(2) (March - April), 2931.

101. Ali, M. Shah Nowaz. (1995). Working Capital problems of Rajshahi jute mills: A case study. Rajshahi University Studies, 3, 151-160.

102. Ali, Mahmud Mahboob. (1996-1997). Machinnous Demand for Money Fucntion: Case of Bangladesh. Journal of the Institute of Bankers, Bangladesh. $44 \& 45$. (December - June), 54-66.

103. Ali, Muhammad Mahboob. (1996-1999). Relationship between Money Supply process and Expansion of Bank Branches in Bangladesh: An Empirical Study. Business Review, 2(2) (July-June), 57-65.

104. Ali, Muhammad Mohsin. (1979). Rural Credit in Bangladesh. Journal of the Institute of Bankers, Bangladesh. 9. (June), 5-15.

105. Ali, Syed Ashraf. (1978). Brief For Bankers - Exchange Rate Structure in Bangladesh: Policy and Operation. Bank Parikrama, 3(3 \& 4) (September \& December).

106. Allen, David. (1993). Strategic Financial Management. The Bangladesh Accountant, 21(4) (October - December), 43-45.

107. Aphulluddin Md. (1993). Overhead Costs and their Control in large Scale Industries. The Cost \& Management Journal. 21(6) (November-December), 19-23.

108. Ara, Laila Arjuman. (2006). Model Identification for measuring stock Market volatility: A study of Chittagong Stock Exchange. Journal of Business Studies (EWU), 2(2) (July), 57-66.

109. Arefin, K. \& Hossain Md. J. \& Islam ABM. S. (1999). Use of Non Financial Indicators to Measure Performance of the Manufacturing Firm. The Dhaka University Journal of Business Studies, 20(1) (June), 209-232.

110. Ashraf, Mohammad A. \& Rodriguez, Gabriel. Estimated Long Memory Fractional Parameter and Its Impact on the Volatility of Financial Markets. North South Business Review, 1, 1-16.

111. Ather, S. A. (1980), Growth of Indigenous Private Commercial Banks - A Retrogressive Step. Bank Parikrama, 5(3 \& 4) (September \& December).

112. Ather, S. A. (1981). Credit Management. Bank Parikrama, 6(1 \& 2) (March \& June).

113. Ather, S. A. (1982). Role of banks in the Eradication of Poverty From our Society. Bank Parikrama, 7(1 \& 2) (March \& June).

114. Ather, S. M., Solaiman, Md. (1993). Techniques of Risk Measurement in Capital Budgeting Decisions - A Theoretical Overview. The Cost \& Management Journal. 21(3) (May - June), 4-6.

115. Ather, SM. (1991). Applications of Risk Analysis. The Bangladesh Accountant, 19(12) (October - December), 46-53.

116. Ather, Syed Md. (1984). Ratio as a Tool of Financial Decision Making. The Cost \& Management Journal. 12(2) (March - April), 35-44.

117. Ather, Syed Mohammad \& Misir, M. Abu. (2000). Return - Risk Analysis: Measurement of Bank's Performance. The Cost \& Management Journal, 28(5) (September - October), 13-17.

118. Azad, Abul K. (2000). Banking Structure in Bangladesh: Regulatory Framework and Reforms. The Dhaka University Journal of Business Studies, 21(2) (December), 237-261.

119. Azad, Abul K. (2002). Behaviour of Treasury Bills Market in Bangladesh. Journal of Business Studies, 23(2) (December), 285-302. 
120. Azad, Abul Kalam. (2001). Does Insurance Contribute Significantly to the Capital Market Development in Bangladesh? Bank Parikrama, 26(3 \& 4) (September \& December).

121. Azad, ASM Sohel, Ali, Anwar. (2001). Factoring Concepts, Mechanics and its Application in Bangladesh. The Bangladesh Accountant, 32(5) (January March), 58-71

122. Azad, Md. A K. (2000). Lending Strategy, Policy and procedure in Financing Small scale Industry: A case study of Bank of Small Industries and Commerce Bangladesh Limited. The Dhaka University Journal of Business Studies, 21(2) (December), 163-182.

123. Azim, Mohammad I. \& Hussain, S. M. (1999). Operational Performance of BJMC and BJMA: A Comparative Study. The Dhaka University Journal of Business Studies, 20(1) (June), 1-23.

124. Aziza, Tasnima, Rana, Md. Baktiar \& Islam, Mohammad Nazmul. (2005). Profitability of NCBs and PCBs in Bangladesh: A Focus on Ancillary Business Income in the 1990s. Journal of Business Research, 7(June), 33-48.

125. Bagchi, Debasis. (2003). Corporate Governance Index and Capital Market Behavior: Indian Experience. The AIUB Journal of Business and Economics, 1(4) (August), 63-78.

126. Bahar, Habibullah. (1977). Development of Banking in Bangladesh since Nationalization. Journal of the Institute of Bankers, Bangladesh. 5. (June), 1-5.

127. Bahar, Habibullah. (1984). Financing small enterprises in Bangladesh. Journal of the Institute of Bankers, Bangladesh. 19. (June), 30-41.

128. Bahar, Habibullah. (1988). Financial deeping in Bangladesh: A Preliminary study. Journal of the Institute of Bankers, Bangladesh. 27. (June), 21-26.

129. Bahar, Habibullah. (1989). An Evaluation of banks in Bangladesh: The exploratory Approach. Bank Parikrama 14.

130. Bahar, Habibullah. (1993). Behaviour of Bank Deposits in Bangladesh: Some Empirical Findings. Bank Parikrama, 18.

131. Bairagi, Ranajit Kumar. (2003). Signaling Effect of Dividend policy on Share Prices in Bangladeshi Capital Market. Bank Parikrama, 28(1) (March).

132. Bakar, Md. Abu. (1983). Analysis and Interpretation of Financial Statement for Credit Appraisal. Bank Parikrama, 6(3 \& 4) (September \& December).

133. Bakar, Md. Abu., Sirker, M. Nizamuddin \& Paul, Nilima Rani. (1994). Capital Market in Bangladesh: Problems and Prospects. Bank Parikrama, 19(3 \& 4) (September \& December).

134. Bala, Swapan K. \& Habib, A. (1997). Investment Performance Evaluation: A study on Investment Corporation of Bangladesh (ICB) Mutual Funds. The Dhaka University Journal of Business Studies, 18(2) (December), 249-265.

135. Bala, Swapan K. \& Yusuf Mohammed A. (2003). Corporate Environmental Reporting in Bangladesh: A Study of Listed Public Limited Companies. Journal of Business Studies, 24(1) (June), 31-45.

136. Bala, Swapan Kumar. (1993). A Test of Market Efficiency: A Study of Dhaka Stock Exchange. Journal of Business Administration, 19(3 \& 4) (July \& October).

137. Banarjee, Prashanta K. \& Sarker, Md. M. R. (1996). Break-Even Point: A project Appraisal Technique Used in Banking Sector. The Dhaka University Journal of Business Studies, 17(2) (December), 175-186.

138. Banerjee, Prashanta. (1996). Trends and Monitoring of profitability in banking sector. The Bangladesh Accountant, 24(4) (October - (December), 98-105 
139. Banerjee, Prashanto K., Rahman, Md. Saidur \& Chowdhury, Mainul Islam. (2005). Debt Market in Bangladesh. Bank Parikrama, 30(2) (June).

140. Banerjee, Prashanto Kumar. (2002). Performance Evaluation of Indian Factoring Business: Some Lessons for Bangladesh. Bank Parikrama, 27(1) (March).

141. Banik, Dulal C. (1984). The Role of Finance Executive of a Big Industrial Enterprise In Achieving its Objectives. The Cost \& Management Journal. 12(6) (NovemberDecember), 47-50.

142. Banik, Dulal C. (1985). The Significance and Limitations of Capital Budgeting in the Investment Decision. The Cost \& Management Journal. 13(3) (May - June), 19-20.

143. Banyard, Cyril. (1987). Value For Money: The Accountant's Contribution. The Cost \& Management Journal. 15(6) (November-December), 5-10.

144. Barai, Munim Kumar \& Moral, Md. Liakat Hossain. (1999). Globalization of Bangladesh Economy: Trade, Financial and Investment Issues. Journal of Business Research, 2, 55-71.

145. Barket-e-Khuda Alam, M. M. (1991). Financing Programmes in Health and Population Sector of Bangladesh and the Issue of Sustainability. The Dhaka University Journal of Business Studies, 12(1) (June), 45-61.

146. Barua, Abhijit \& Mamun, Muhammad Z \& Islam, Nazrul. (2000). Performance of the Nationalized General Insurance Company of Bangladesh. Bank Parikrama, 25(4) (December).

147. Barua, Abhijit. (2001). Liquidity Scenario in Commercial Banks of Bangladesh: Liquidity Shortage in 1995, Before and After. Journal of Business Research, 3, 75-90.

148. Baset, Imtiaz Lutful. (1998). Business Continuity Plan: An Essential Component of Risk Management. The Bangladesh Accountant, 26(4) (October - (December), 128-133.

149. Bashar, Md. Abdul, Rahman, M. Lutfor. (1990-1991). Availability and utilization of farm credit in an Area of Mymensingh District. Bank Parikrama, 15 \& 16.

150. Bashar, Omar Khaled Mohammad Rizwanul \& Islam, Mohammd Shofiqul. (2003). Grameen Banks Micro Credit Model: A comparative Study with Bangladeshi Commercial Bank's Performance. The AIUB Journal of Business and Economics, 1(3) (January), 50-65.

151. Bayes, Abdul. (1987). Bangladesh Banking: Growth, Structure and Performance. Bank Parikrama, 12(2) (June).

152. Begum, Nazma. (1998-2000). Unanticipated Money Growth \& Investment. Journal of the Institute of Bankers, Bangladesh. 47. (June - December), 1-12.

153. Belal, Ataur Rahman. (1998). Corporate Take-Over and Merger: Theory and Evidence. The Cost \& Management Journal, 26(6) (November-December), 8-10.

154. Belal, Mr. Ataur Rahman. (2000). Earning Per Share (EPS) reporting in Bangladesh. The Cost \& Management Journal, 28(4) (July - August), 16-20.

155. Bhattacharjee, Durgadas \& Karmaker, Shyam S. (1989). Performance Evaluation Measures of a Public Sector Enterprise: A Critical Review. The Dhaka University Journal of Business Studies. 10(2) (December), 191-203.

156. Bhattacharjee, Durgadas, Saha, Saroj Kumar. (1989). An Evaluation of Performance if NCBs in Bangladesh. Bank Parikrama, 14.

157. Bhattacharjee, Durgadas. (1985). Managerial Performance of the Public Sector Industry: A review of Concepts and trends of performance of Sugar Industry in Bangldesh. The Dhaka University Journal of Business Studies, 6(1) (June), 75-94. 
158. Bhattacharjee, Durgadash. (1990). Productivity Measurement in the nationalized Commercial Banks of Bangladesh: A Multivariate Analysis (Part 1). The Dhaka University Journal of Business Studies, 11(2) (December), 181-193.

159. Bhattacharjee, Durgadash. (1991). Productivity Measurement in the nationalized Commercial Banks of Bangladesh: A Multivariate Analysis (Part 2). The Dhaka University Journal of Business Studies, 12(1) (June), 25-44.

160. Bhattacharjee, H \& Rahman, Md. L. (1999). Health Insurance: Theories and Evidence with Specific Reference to Bangladesh. The Dhaka University Journal of Business Studies, 20(1) (June), 77-96.

161. Bhattacharyya, D. P. (1983). Cash Budget - An effective means to solve liquidity problems. The Cost \& Management Journal. 11(5) (September-October), 3540 .

162. Bhowmik, Bulbul. (1985). Alternative Investment Opportunities for Small Savers. The Dhaka University Journal of Business Studies, 6(1) (June), 65-73.

163. Bhowmik, Bulbul. (1986). A Comparative Study of BSB and BSRS Performance, 19721985. The Dhaka University Journal of Business Studies, 7(2) (December), 101-121.

164. Bhuiyan, Md. Nazim Uddin \& Khan, Sajjad Hossain. (2002). Life Insurance Business in Bangladesh: A Synopsis of Development. The Cost \& Management Journal, 30(50) (September - October), 4-8.

165. Bhuiyan, Md. Nazim Uddin, Islam Md. Ainul. (1997). Lease Financing: A Hybrid Financial Activity Comprising Financial and Investment Decision. The Cost \& Management Journal. 25(2) (March - April), 11-16.

166. Bhuiyan, Md. Nazim Uddin, Islam, Md. Ainul, Firozzaman, Md. (1997). Lease Financing. The Bangladesh Accountant, 25(1) (January - March), 140.

167. Bhuiyan, Md. Nazim Uddin. (1993). Financial Information: Quantative and Qualitive Expectation of the Users. The Cost \& Management Journal. 21(3) (May June), 18-22.

168. Bhuiyan, Md. Nazim Uddin. (1996). Leasing the Nationalised Industries or Use of Leasing in Denationalisation: A Viable Alternative to Disinvestment. The Cost \& Management Journal. 24(6) (November-December), 19-22.

169. Bhuiyan, Md. S. (1982), Inflation and Insurance. The Dhaka University Journal of Business Studies, 3(1) (December), 111-122.

170. Bhuiyan, Mohammad Mominul Hoque, Salat, Amirus, Rahman, Muhammad Zahedur. (2003-2004). Performance evaluation of the Companies after Initial public offerings. The Bangladesh Accountant, 42(15) (October-March), 120-127.

171. Bhuiyan, Mohsin. (1992). Utilization of sale proceeds of fixed assets to meet deficiency of working capital. The Bangladesh Accountant, 20(3) (July - September), 5660.

172. Bhuiyan, Rafiqul H. \& Hossain. M. K. (1990). Performance Dynamics of Nationalized Commercial Banks in Bangladesh - The Case of Sonali Bank. The Dhaka University Journal of Business Studies, 11(1) (June), 163-174.

173. Bidisha, Sayema H., Alam, Mahbub \& Ahsanuzzaman. (2005). How volatile are the Stocks of the Pharmaceutical Companies of Bangladesh? Some Evidences from the Market Model. Bank Parikrama, 30(2) (June).

174. Bin Hoque, H. A. A \& Khan, Azizur R. (2001). Financial Performance of Banks: A Statistical Analysis. The Dhaka University Journal of Business Studies, 22(2) (December), 26-50. 
175. Bukhari, Syed, Monwar Hossain. (1993). Housing Finance and Institutions in Bangladesh: Proposal for reorganizations. The Jahangirnagar Economic Review. 8(1) (June), 57-74. Dept. of Economics, Jahangirnagar University

176. Chattarjee, B. K. (1984). Long Range Financial Planning. The Cost \& Management Journal. 12(4) (July - August), 15-20.

177. Chaudhury, Sulaiman. (1979). Rational and Role of Public Sector in Industrial Development with Special Reference to Bangladesh. Bank Parikrama, 4(1 \& 2) (March \& June).

178. Choudhuri, A. H. M. Nurul Islam, Choudhuri, Toufic. (1993). Performance of Private Commercial banks Vis-a- Vis banking Sector. Bank Parikrama, 18.

179. Choudhuri, A. H. M. Nurul Islam, Saha, Sujit Ranjan, Choudhury, Toufic A. Choudhury. (1992). Status of Capital Market in Bangladesh: An Overview. Bank Parikrama, 17.

180. Choudhuri, A. H. M. Nurul Islam, Shahid, A. T. M. Abdus. (1993). Banks in financing small scale industries in Bangladesh. Bank Parikrama, 18.

181. Choudhuri, A. H. M. Nurul Islam., Choudhury, Toufic Ahmed \& Saha, Sujit Ranjan. (1994). Security Portion of Money and Capital Market: Growth, Constraint and Possible Linkage with Banking Sector. Bank Parikrama, 19(3 \& 4) (September \& December).

182. Choudhuri, A. H. M. Nurul Islam., Roy, Mihir Kumar. (1993). Bank Finance, Technological and Agricultural Development. Bank Parikrama, 18.

183. Choudhuri, A. H. Nurul Islam., Choudhury, Toufic Ahmad. (1993). Financial Sector Reforms, Measures, outcome and Probable Future Action. Bank Parikrama. 17 (3 \& 4) (September- December).

184. Choudhury, A. H. M. Nurul Islam, Choudhury, Toufic A. (1992). Financial Liberalization in Bangladesh: Conceptual Issues and Impact on Banking Financial Institutions. Bank Parikrama, 17.

185. Choudhury, Md. Omar. (1978). Financial Analysis - A Few Common Notations. Bank Parikrama, 3(1) (March), 16-25.

186. Choudhury, Md. Omar. (1978). Funds Statement and Fund Flow Analysis. Bank Parikrama, 3(3 \& 4) (September \& December).

187. Choudhury, Sanawar Mohammed Islam. (2004). Financial Services Outsourcing: Is Bangladesh Ready to capture a slice of the $\$ 400$ billion cake? The Bangladesh Accountant, 44(14) (July - September), 5-6.

188. Choudhury, Toufic A. (1989). Development of commercial Banking in India Since 1969. Bank Parikrama, 14.

189. Choudhury, Toufic Ahmad. (1998). Impact of Denationalization and Privatization on the Profitability and Productivity of the Commercial Banks of Bangladesh. Bank Parikrama. 23 (October).

190. Chowdhury A. A. M. U \& Chowdhury, Tanbir A. (1997). Role of "Securities and Exchange Board of India (SEBI)" in The Development of Indian Capital Market: Lessons for Bangladesh. The Dhaka University Journal of Business Studies, 18(2) (December), 77-96.

191. Chowdhury A. A. M. U \& Chowdhury, Tanbir A. (1998). An Evaluation of the Role of Investment Corporation of Bangladesh (ICB) in the Development of Bangladesh Capital Market. The Dhaka University Journal of Business Studies, 19(2) (December), 75-94.

192. Chowdhury A. A. M. U. (1996). Corporate Finance in Japan: Experience from the Past. The Dhaka University Journal of Business Studies, 17(1) (June), 45-60. 
193. Chowdhury, A. A Mahboob Uddin. (2004). Corporate Governance in Bangladesh: Some observations. Finance and Banking, 6(1 \& 2) (June-December), 63-82.

194. Chowdhury, A. A. Mahboob Uddin \& Chowdhury, Tanbir Ahmed. (2005). The Role of Agency and Bankruptcy Costs for the Determination of Capital Structure: A Survey of Theory and Evidence. Journal of Business Studies, 26(2) (December), 127-149.

195. Chowdhury, A. A. Mahboob Uddin Chowdhury. (2004). Capital Structure: Evidence from Japan and Bangladesh. Journal of Business Studies, 25(1) (June), 17-55.

196. Chowdhury, A. K. (2003). Capital Market - Corporate Governance - Regulatory Regime. The Bangladesh Accountant, 39(12) (January - March), 106-109.

197. Chowdhury, D. (1994). Agency Costs and Corporate Governance: Evidence from Literature. The Dhaka University Journal of Business Studies, 15(1) (June), 161-182.

198. Chowdhury, Dhiman Kumar. (1986). Capital Budgeting in the 1986's. The Cost \& Management Journal. 14(2) (March - April), 27-30.

199. Chowdhury, Jamal Ahmed, Anowar, A. S. M. (1997). A Critical Review of the Existing Fiscal Incentives for Investment in Bangladesh. The Cost \& Management Journal. 25(1) (January - February), 22-26.

200. Chowdhury, Md. Abdul Mannan. (1992-1995). Relative Performance of Nationalized Commercial Banks and Private Commercial Banks: A critical Analysis. Journal of the Institute of Bankers, Bangladesh. 36 to 41. (December - June), 80-99.

201. Chowdhury, Ranjit Kumer. (1990). Factors Influencing the Financial Structure of Small sale industries: A Case study. The Cost \& Management Journal, 18(1) (January - February), 22-29.

202. Chowdhury, Shah Saeed Hasssan \& Sadique, M. Shibley. (2002). The Effect of Foreign AID on the Economic Growth of the SAARC Members. Rajshahi University Studies, 10, 1-14.

203. Chowdhury, Tanbir Ahmed. (2005). Stock Market behavior in Bangladesh. Journal of Business Studies (EWU), 3(1 \& 2), 47-77.

204. Chowdhury, Tanbir Ahmed. (2006). An Appraisal of the activities of Investment corporation of Bangladesh. Journal of Business Research, 8(June), 47-62.

205. Chowdhury, Tanbir Ahmed., Uddin, Mohammad Riaz \& Hoque, Hafiz Al Asad Bin. (2004). An empirical Investigation of Risk-Return Relationship in Bangladesh: Evidence from CAPM. Finance and Banking, 6(1 \& 2) (JuneDecember), 83-96.

206. Chowdhury, Toufic A., Saha, Sujit Ranjan. (1991-1992). Non-Bank Financial Industries in Bangladesh Some Observations on Performance \& regulations. Journal of the Institute of Bankers, Bangladesh. 34 \& 35. (December - June).

207. Chowdhury. (2002). Differential Auto Regressive Model for Sales Forecast in American High Tech Company. Journal of Business Administration, 28(3 \& 4) (July \& October).

208. Damania, H. M. (1980). Interpretation of Financial Statements. The Bangladesh Accountant, 3(8) (April-June), 22-40.

209. Das, Jagdish C. S. \& Hakim. Md. A. (1995). Awareness and Use of Forecasting Techniques in Business. The Dhaka University Journal of Business Studies, 16(2) (December), 175-183.

210. Das, Mahim Chandra. (1979). Development of Capital Market in Underdeveloped Countries with special Reference to Bangladesh. Bank Parikrama, 4(1 \& 2) (March \& June). 
211. Debnath, B. B. (1976). Institutional Finance and Small Borrowers. Journal of the Institute of Bankers, Bangladesh. 4. (December), 7-14.

212. Dewan, Z. A. (1993). Banks and Agricultural Development: Some Experiences of Bangladesh Krishi Bank. Bank Parikrama, 18.

213. Dutta, Dipak Kanti, Mazumder, Bidhan Chandra. (2004). Inventory Control and its Impact on Overall Performance of a Pharmaceutical Compan: A Study on Glaxo Wellcome Bangladesh Limited. The Cost \& Management Journal. 32(4) (July - August), 16-23.

214. Ema, Sharmin K. \& Sharif, Taimur R. (2003). Financing For Human Capital Accumulation in Bangladesh: A Macroeconomics Study. Journal of Business Studies, 24(1) (June), 197-211.

215. Habib, A. (1998). Readability of Corporate Annual Reports: Bangladesh Scenario. The Dhaka University Journal of Business Studies, 19(2) (December), 263-273.

216. Habib, Ahsam \& Al-Amin. (2006). Determinants of Corporate Cash Holdings in Bangladesh An Empirical Evaluation. Journal of Business Studies, 27(1) (June), 165-185.

217. Habib, Ahsan \& Akhter, Salat. (2003). Empirical Evaluation of the Time Series Behavior of Return on Equity (ROE): Bangladesh Evidence. Journal of Business Administration, 29(1 \& 2) (January \& April).

218. Habib, Ahsan \& Al-Amin. (2006). Fundamental Analysis and Prediction of Corporate Earnings: Bangladesh Evidence. Journal of Business Administration, 32(1 \& 2) (January \& April).

219. Habib, Ahsan. (2004). Do Dividends Signal the Future: Empirical Evidence From Bangladesh. Journal of Business Administration, 30(1 \& 2) (January \& April).

220. Habibullah, A. K. Md. (1983). A Treatise on Fund Management: A Case of Excess Liquidity in 1983. Bank Parikrama, 8(3 \& 4) (September \& December).

221. Habibullah, M. (1980). Industrial Financing and institutional Arrangement for setting up Industries in the Private Sector. The Dhaka University Journal of Business Studies, 1(2) (June), 73-80.

222. Habibullah, M. (1991). Efficacy of budget: A Case Study of a Public Corporation. The Dhaka University Journal of Business Studies, 12(1) (June), 17-24.

223. Habibullah, Md. (1993). Social Accounting. The Cost \& Management Journal. 21(4) (July - August), 14-17.

224. Hakim, Md. A. (1996). Financing the Ethnic Minority Business in Britain: A Case Study of Bangladeshi Enterprises. The Dhaka University Journal of Business Studies, 17(2) (December), 143-158.

225. Hanan, Chowdhury. (1995). Association between Long-Run Executive Incentive Plans of Corporate Capital Expenditure. Journal of Business Administration, 21(1 \& 2) (January \& April).

226. Haq, Ataul. (1993). Financial Sector Reform in Bangladesh. Bank Parikrama, 18.

227. Haq, Zahirul A. T. M. (1988). Capital Output Ratio in the Railway Sector of Bangladesh. Journal of Business Administration, 14(4) (October).

228. Haque, A. K. M. Zahirul. (1986). Risk and Uncertainty in Capital Investment Decisions. Bank Parikrama, 11(3 \& 4) (September \& December).

229. Haque, M. M. \& Nabi, M. N. (2002). Credit proposal Appraisal system of commercial bank with special emphasis on 'LRA' technique: An Exploratory study on prime bank. Business Review, 3(1) (June), 29-35.

230. Haque, M. Mainul. (1988). Industrial Financing in Bangladesh and Need for Entrepreneur Development. Bank Parikrama, 13. 
231. Haque, M. Shamsul. (1988). Working Capital Management: Theory and Practice in Bangladesh. Bank Parikrama, 13.

232. Haque, M. Shamsul. (1992). Development of Capital Market in Bangladesh. Bank Parikrama, 17.

233. Haque, Md. Nazmul, Talukder, Md. Serajul Islam. (1986). Effectiveness of Interest Rate Policies in Bangladesh. Bank Parikrama, 11(3 \& 4) (September \& December).

234. Haque, Shamsul \& Eunus, Ahmed Mahiuddin. (1998). Return \& Market Efficiency in a Capital Market under Distress: Story and Evidence from Dhaka Stock Exchange, Bangladesh. Journal of Business Administration, 24(3 \& 4) (July \& October).

235. Hasan, Abu H. R \& Jalil A. (1995). Efficiency through Competition: Comparison of Commercial Banks of Bangladesh in Respect of Several Dimensions Deposits. The Dhaka University Journal of Business Studies, 16(1) (June), 113-130.

236. Hasan, Abu H. R. (1995). Tracking Inflation Rates: A Box-Jenkins ARIMA Model for Bangladesh. The Dhaka University Journal of Business Studies, 16(2) (December), 125-141.

237. Hashem, Abul. (1982). Port Folio Management in an Inflationary Economy. Bank Parikrama, 7(1 \& 2) (March \& June).

238. Hassan, A. F. M. Kamrul \& Islam, M. Rafiqul. (2006). Financial Sector reform and Competition in banking sector in Bangladesh: A Preliminary Assessment. Journal of Business Administration, 32(3 \& 4) (July \& October), 79-104.

239. Hassan, M. Kabir. (1994). A Comparative Analysis of the American, Japanese and German banking System. Bank Parikrama, 19(1 \& 2) (March \& June).

240. Hassan, M. N. (1978). Cost and Budgetary Control in Bangladesh Film Industry. The Cost \& Management Journal. 5(2) (January - June).

241. Hassan, M. N. (1978). Cost and Budgetary Control Needed in Jute Industry. The Cost \& Management Journal. 5(2) (July - December).

242. Hoque, A. K. M. Z. (1988). Capital Structure Patterns: A study of Companies Listed on the Dhaka Stock Exchange. The Dhaka University Journal of Business Studies, 9(2) (December), 133-149.

243. Hoque, A. K. M. Zahirul Hoque. (1989). Some Issues of Corporate Capital Structure: A case study of Engineering Industries Listed on Dhaka Stock Exchange. The Cost \& Management Journal, 17(4) (July - August), 23-29.

244. Hoque, Hafiz Al Asad Bin., Kabir, Muhammad Mujibul \& Rahman, M. Masud. (2005). Printability of Stock Returns: Evidence from conventional and new variance Ratio Test. Finance and Banking, 7(1 \& 2) (June-December). 1-18.

245. Hoque, Md. Ataul. (1991). Leasing - An Alternate Source of Finance. The Bangladesh Accountant, 12(10) (April-(June), 32-33.

246. Hoque, Md. Jahirul. (1984). Pattern of Financing Working Capital - A Case study of some Manufacturing Enterprises in Bangladesh. The Cost \& Management Journal. 12(3) (May - June), 17-24.

247. Hoque, Md. Jahirul. (1985). Impact of Poor Working Capital Management on Performance of Jute Industry in Bangladesh. The Journal of Management Business \& Economics, 11(2) (April).

248. Hoque, Md. Johurul \& Hossan, Mohammad Akter. (2003). Evaluation of Life Insurance Business in Some insurance Companies in Chittagong. Business Review, 3(2) (July-December), 50-58.

249. Hoque, Md. Johurul, Nabi, Kazi Ahmed. (1983). Capitla Investment Decision - A critical Appraisal of some selected Public Sector Industrial Enterprises in 
Bangladesh. The Cost \& Management Journal. 11(6) (November-December), 27-38.

250. Hoque, Monzurul \& Musa, Mohammad. (2001). The Long Term Performance of IPOs in Bangladesh. Journal of Business Administration, 27(1 \& 2) (January \& April).

251. Hoque, Muhammad Nurul. (2004). An Evaluation of the Criteria for Determining the Rural Loan Recovery Behavior in Bangladesh. The Bangladesh Accountant, 43(16) (April-June), 73-76.

252. Hoque, Muhammad Nurul. (2004). Exchange Rate Management: A Case Study in Commercial Banks of Bangladesh. The Bangladesh Accountant, 44(14) (JulySeptember), 27-33.

253. Hossain, ATM Tofazzel. (1992). Working Capital Management: A Comparative study of public sector \& private sector jute mills. The Bangladesh Accountant, 20(3) (July - September), 67-77.

254. Hossain, C. M. S \& Hossain Md. A. \& Islam, ABM S. (2001). Relevance of Gordon Model on Share Price Behaviour - The Case of Bangladesh. The Dhaka University Journal of Business Studies, 22(2) (December), 325-338.

255. Hossain, H. M. Mosarof \& Haque, Mohammad Nurul: Haider Md. Badrul. (2004). Comparative Analysis of Accounting Standard Setting Process in Developed Countries \& in Bangladesh. Finance and Banking, 6(1 \& 2) (June-December), 11-32.

256. Hossain, H. M. Mosarof. (2004). Capital Market of Bangladesh: Some Observations. Finance and Banking, 6(1 \& 2) (June-December), 115-128.

257. Hossain, H. M. Mosarof. (2006). Empirical Evidence from Determination of Stock Price and Return of DSE. Finance and Banking, 8(1 \& 2) (June-December). 111-132.

258. Hossain, Kazi Akhter, Rahman, M. Mahbubur. (2003). E-Banking - A case study on Private commercial banks in Bangladesh. The Bangladesh Accountant, 39(12) (January - March), 30-36.

259. Hossain, Khondoker Shafayet Hossain \& Islam, S. M. Ebadul. (1996-1999). Financial Performance Analysis through Ratios: A Case Study of Khulna Newsprint Mills Limited. Business Review, 2(2) (July-June), 50-56.

260. Hossain, M. Mokharrom. (1988). Capital Structure and Profitability: A Case Study of Crescent jute mills Ltd. Khulna. Bank Parikrama, 13(1 \& 2) (March \& June).

261. Hossain, Mahmud. (2001). Accounting Earnings, Cash Flows and Stock Returns. The Bangladesh Accountant, 32(5) (January - March), 31-36.

262. Hossain, Md Afzal, Nizami, Md. Helal Uddin, Rahman, Md. Mizanur. (1994). Nationalisation and Denationalisation of Commercial Banks in Bangladesh: Leading Factors. The Cost \& Management Journal. 22(3) (May - June), 31-33.

263. Hossain, Md. Abul, Sen, Dilip Kumar. (1997). A Brief audit of cost capital. The Bangladesh Accountant, 25(3) (July - September), 143-150.

264. Hossain, Md. Akmal. (1979). Financing Non-Farm Rural Enterprises. Bank Parikrama, $4(1 \& 2)$ (March \& June).

265. Hossain, Md. Akmal. (1980). Financing the New Entrepreneur. Bank Parikrama, 5(3 \& 4) (September \& December).

266. Hossain, Md. Akmal. (1980). Recovery of banks Advances - Sector Wise. Bank Parikrama, 5(1 \& 2) (March \& June).

267. Hossain, Md. Akmal. (1982). Performance Budgeting and its Feasibility for National Commercial Banks of Bangladesh. Journal of the Institute of Bankers, Bangladesh. 15. (June), 33-42. 
268. Hossain, Md. Motaher, Khaled, Md. Sarower (2003). A study on Growth of Insurance in Bangladesh: 1990-2001. The Jahangirnagar Review, 27 (June).

269. Hossain, Md. Shahadat. (2001). Break-Even and CVP Analysis: Its applicability in Banning Industry. The Cost \& Management Journal, 29(1) (January February), 32-34.

270. Hossain, Mohammad Farhad. (1999). Who are More Concerned about the ROI, Academic or Firms? Journal of Business Research, 2, 21-28.

271. Hossain, Mohammad Farhad. (2004). Days of the weak effect in Dhaka Stock Exchange: Evidence from small portfolios of Banking Sector. The Jahangirnagar Review, 28(Part ii) (June)

272. Hossain, Mohammad, Farhad, Siddiquee, Md. Moriruzzaman, Islam, K. M. Zahidul. (2006). Effect of new IPO issuance on the secondary Market: Evidence from DSE. The Jahangirnagar Economic Review. 17(1) (June), 1-16.

273. Hossain, Monowa \& Arefin, Kamrul. (2005). Bangladesh Bank Full Autonomy - Too Early or Too Late - An Evaluation. Journal of Business Research, 7(June), 4960.

274. Hossain, Syed Zabid Hossain., Hossain, Khondoker Shafayet \& Islam, S. M. Ebadul. (1998). Capital Structure Management: A study on the Enterprises of Bangladesh Sugar and Food Industries Corporation. The Cost \& Management Journal, 26(4) (July - August), 16-20.

275. Hosssain, Md. Akmal. (1982). Financing the small farmers - problems and remedial measures. Bank Parikrama, 7(1 \& 20) (March \& June).

276. Houque, Md. Nurul. (2005). Measuring Stock Market Behavior: A case study of Dhaka Stock Exchange. Journal of Business Studies, 26(2) (December), 61-73.

277. Howlader, Sushil Ranjan \& Khan, Harun-ar-Rashid. (1988). Bank Deposits in Bangladesh: Levels Trends and Determinants. Journal of Business Administration, 14(4) (October).

278. Howlader, Sushil Ranjan. (1987). Portfolio Selection and Demand for Assets in a Peasant Economy: A Theoretical Analyses. The Dhaka University Journal of Business Studies, 8(2) (December), 185-199.

279. Huda, M. Nazrul. (1988). Approach of Money Supply Analysis. Journal of the Institute of Bankers, Bangladesh. 27. (June), 27-39.

280. Huda, M. Nazrul. (1990-1991). Financial Sector reforms in Bangladesh. Journal of the Institute of Bankers, Bangladesh. 31, 32 \& 33. (June - December), 5-15.

281. Huq, A. \& Moyeen, A. F. M. (1994). Theories of Growth of Small Business: A Critical Review. The Dhaka University Journal of Business Studies, 15(1) (June), 141159.

282. Huq, Begum Ismat Ara \& Misir, M. Abu. (2005). Insider Trading around Dividend Announcements in Bangladesh. The Cost \& Management Journal, 33(5) (September - October), 5-15.

283. Huq, Begum Ismat Ara \& Parveen, Jannat Ara. (2000). Foreign Exchange Business in Conventional and Interest Free Islamic Banks in Bangladesh. The Cost \& Management Journal, 28(2) (March - April), 15-18.

284. Huq, Begum Ismat Ara, Jannat Ara Parveen. (1994). Role of Rural Financial Markets in Rural Development of Bangladesh - A Case Study. The Cost \& Management Journal. 22(5) (September - October), 35-37.

285. Huq, Begum Ismat Ara. (1992). Impact of Poor Management of receivables on Financial Performance: A Case study of some Public Sector Chemical \& Paper Mills in Bangladesh. The Cost \& Management Journal. 20(4) (July August), 26-31. 
286. Huq, Begum Ismat Ara. (2004). An analysis of Leverage- A comparative Analysis of some public and private sector chemical industries in Bangladesh. Business Review, 4(1 \& 2) (December), 13-20.

287. Huq, M. Azizul. (1996). Islamic Banking in Bangladesh with a brief Overview of Operational Problems. Bank Parikrama, 21(1 \& 2) (March \& June).

288. Hussain, Syed M. (1990). Profitability Analysis in Mechanized Inland Water Transportation of Bangladesh. The Dhaka University Journal of Business Studies, 11(2) (December), 113-122.

289. Hussain, Tashfeen., Selim, Sheikh Tareq \& Zaved, Shejad. (2003). Does Finance make a Difference? The AIUB Journal of Business and Economics, 1(4) (August), 43-62.

290. Hussaun, S. M \& Islam Md. A. (2001). Banking in Bangladesh: A Historical Perspective. Journal of Business Studies, 22(2) (December), 309-333.

291. Ijiri, Yuji, Trueblood Robert M. (1984). Recovery Rate and Cash Flow Accounting. The Cost \& Management Journal. 12(1) (January - February), 13-18.

292. Imam, Mahmood C. \& Kabir, Muhammad M. (2001). Priority Sector Loan Pricing: Is It a Constraint to Profit Maximization Behavior of NCB's in a Semi-Liberalized Regime? Journal of Business Studies, 22(2) (December), 249-262.

293. Imam, Mahmood O. (1989). Stock Market Development: A perspective of Investment Corporation of Bangladesh. The Dhaka University Journal of Business Studies, 10(1) (June), 79-101.

294. Imam, Mahmood O. (1997). The Costs of Going Public and Flotation Method Selection-Evidence from the Belgian Market. The Dhaka University Journal of Business Studies, 18(1) (June), 1-52.

295. Imam, Mahmood Osman, Amin, Abu, saleh, Md. Muntasir. (2004). Volatility of Stock Return: Evidence from DSE. Journal of the Institute of Bankers, Bangladesh. 51. 1(June).

296. Ishtiaque, Abu Naser. (2000). Lease Finance in Bangladesh - A Market Overview. The Bangladesh Accountant, 28(1) (January - March), 87-94.

297. Islam, A. F. M. M. (1991). Increasing Need for Institutional Credit in Agricultural Sector of Bangldesh. The Dhaka University Journal of Business Studies, 12(1) (June), 181-188.

298. Islam, A. F. M. Mafizul. (1993). Agricultural Development with Bank Credit. Bank Parikrama, 18.

299. Islam, Abu Sayed Md. Shaykhul. (1992). Tea-Cultivation - Investment Criteria. The Cost \& Management Journal. 20(4) (July - August), 36-39.

300. Islam, Aminul. (1979). Capital Investment Analysis: Cost Concepts and Evaluation Techniques. The Cost \& Management Journal. 6(3 \& 4) (October-December), 19-26.

301. Islam, K. M. Zahidul, Siddiquee, Md. Moniruzzaman \& Rahman, Masud Ibn. (2006). Book-Building system: Will it really help to build the market? Journal of Business Research, 8(June), 63-76.

302. Islam, M. M \& Khan, Salahuddin A \& Khalily, M. A. B. (2001). Financial, Liberalization, Banking Sector and Industrial Finance Stagnancy or Dynamism? Journal of Business Studies, 22(2) (December), 1-27.

303. Islam, M. Shahidul \& Bashar, Omar Khaled Mohammad Rizwanul. (2004). Financial Crisis and the Question of the Demise of East Asian Miracle: A Critical Review. The AIUB Journal of Business and Economics, 1(5) (January). 15130. 
304. Islam, Md. Kazi Saidul. (1993). Aggricultural Credit Disbursement and Recovery performance: A Case Study. The Cost \& Management Journal. 21(6) (November-December), 40-42.

305. Islam, Md. Mohsin. (1995). Performance Evaluation of Lending Programs of Sugar Mills - A Case Study of Mobarukgonj Sugar Mills. Rajshahi University Studies, 3, 99-116.

306. Islam, Md. Monjurul. (1987). Financial Analysis For Marketing Decision. The Cost \& Management Journal. 15(1) (January - February), 13-17.

307. Islam, Md. Nazmul, Arefin, Kamrul \& Hossain, Md. Motaher. (2005). Small Business Financing: Problems analysis and overcome strategies. Journal of Business Research, 7(June), 91-102.

308. Islam, Md. Nazmul., Rana, Md. Baktiar, Rafique, Shuddasattwa \& Aziza, Tasnima. (2004). Crashing Project Time with Least Cost: A Linear Programming Approach. Journal of Business Research, 6, 13-28.

309. Islam, Md. Nazrul. (1988). Some Aspects of Inventory Management: A Case Study of Ahmed Bawany Textile Mills. The Cost \& Management Journal. 16(1) (January - February), 16-21.

310. Islam, Md. Rabiul. (2006). Corporate Investment and Cash Flow Sensitivity in Bangladesh: Evidence From firm Level Panel Data. North South Business Review, 1, 17-31.

311. Islam, Md. Rafiqul \& Amin, Abu Saleh Mohammed Muntasir. (2005). A Review of Multivariate - Garch Models. Journal of Business Administration, 31(3 \& 4) (July \& October), 95-106.

312. Islam, Md. Rafiqul. (1999). Problems of Capital Market Development in Bangladesh. The Cost \& Management Journal, 27(1) (January - February), 11-14.

313. Islam, Md. Rafiqul. (2002). Trade Policy Liberalization and Performance of Bangladesh Economy. Rajshahi University Studies, 10, 141-150.

314. Islam, Md. S. \& Jalil, M. A. (1989). The Relative Influence of Some Variables on Stock Price: A Multivariate Analysis on the Experience of Dhaka Stock Market. The Dhaka University Journal of Business Studies, 10(2) (December), 173-190.

315. Islam, Md. Sadiqul \& Munira, Sirajum. (2004). IPO Flipping and Its Determinants in Bangladesh. Journal of Business Studies, 25(1) (June), 1-16.

316. Islam, Md. Sadiqul. (1988). Security Investment by the National Commercial Banks. The Dhaka University Journal of Business Studies, 9(1) (June), 177-132.

317. Islam, Md. Saiful. (2003). Industrial Credit Allocation: The Role Of Banking Sector in Bangladesh. Business Review, 3(2) (July-December), 59-65.

318. Islam, Md. Shariful \& Rahman, S. M. Zahidur. (2004). Performance evaluation of Textile sector of Bangladesh. Business Review, 4(1 \& 2) (December), 21-30.

319. Islam, Muhammad Rafiqul \& Ali, Md. Afsar. (2001). A Study on Receivables Management in the Public Sector Paper Mills of Bangladesh. The Cost \& Management Journal, 29(1) (January - February), 13-22.

320. Islam, Muhammad Rafiqul. (1995). Cash management of North Bengal Paper Mills Ltd A case study. Rajshahi University Studies, 3, 117-130.

321. Islam, Nazrul \& Mamun, Md. Z. (2005). Factors for Not buying Life Insurance Policies $\mathrm{n}$ a Developing Country: A Case of Bangladesh. Journal of Business Administration, 31(1 \& 2) (January \& April).

322. Islam, Nazrul. (1994). Insurance in Islam. Business Review, 14-18.

323. Islam, Noor-E-Fatema \& Robbani, Md. Golam. (2002). Self-help credit Program of Rajshahi Krishi Unnayan Bank - An Evaluation. The Cost \& Management Journal, 30(6) (November-December), 15-19. 
324. Jahan, Asma \& Akter, Bilkis. (2006). Analysis of the Loan Syndication Process and Prospect in Bangladesh. Journal of Business Studies, 27(2) (December), 456481.

325. Jahan, R. \& O' Neill, H. (2003). Banking and Industrial Development: A Case Study of Bangladesh. Journal of Business Studies, 24(1) (June), 47-66.

326. Jahan, Sayeeda Bilquis. (1992-1995). Monetary and Banking Reforms in Bangladesh. Journal of the Institute of Bankers, Bangladesh. 36 to 41. (December - June), 130-154.

327. Jahangir, Md. Sawkat. (1997). Financial Ratios as Predictors of Sickness of Industries. The Bangladesh Accountant, 25(4) (October - (December), 111-116.

328. Jahur, Md. Saleh \& Uddin, Md. Jamal. (2002). Lease Capitalization: Some Implications for Financial Analysis. The Cost \& Management Journal, 30(2) (March April), 11-16.

329. Jahur, Mohammad Saleh \& Karim, Mohammad Aminul. (2002). Performance Evaluation of Mutual Funds - A Framework. Bank Parikrama, 27(4) (December).

330. Jahur, Mohammad Saleh \& Nazneen, Suraiya. (2005). Determinants of Dividend Policy - An Empirical Study of Some Select Corporate Sectors in Bangladesh. The Cost \& Management Journal, 33(6) (November-December), 58-68.

331. Jahur, Mohammad Saleh \& Uddin, Md. Jamal. (2002). Lease Capitalization: Some Implications for Financial Analysis. Journal of Business Research, 4, 67-78.

332. Jaim, W. M. H., Rahman, M. L. (1990-91). Disbursement and recovery of agricultural credit in Bangladesh - A Macro-level analysis. Bank Parikrama. 15-16, 48-66.

333. Jamil, Gazi Mohammad Hasan \& Ahmed, Mosabbir \& Bhuiya, Shumana. (2005). Pricing and Bidding Behavior of T-Bills in Bangladesh. The Cost \& Management Journal, 33(6) (November-December), 41-57.

334. Jasimuddin. S. M. (1988). Banks in Alleviation of Rural poverty. Bank Parikrama, 13.

335. Kabir, ANM Jahangir \& Hossain, Md. Amjad. (2002). Banking Sector Reforms in Bangladesh in the Perspective of Financial discipline and Management. Rajshahi University Studies, 10, 62-80.

336. Kabir, Khairul. (1982). Bond Financing of Rural Development. Journal of the Institute of Bankers, Bangladesh. 15. (June), 30-41.

337. Kabir, Md. Humayun. (2002). Corporate Governance in the U. S and Japan: A Comparative Analysis. Journal of Business Administration, 28(3 \& 4) (July \& October).

338. Kabir, Md. Humayun. (2002). Earning Management during Initial Public Offering in Japan. Journal of Business Administration, 28(1 \& 2) (January \& April).

339. Kabir, Muhammad Mujibul., Ahmad, Waqar \& Hoque, Hafiz Al Asad Bin. (2005). Share based bank deposit: Debt or Equity? Implications for Deposit Pricing. Finance and Banking, 7(1 \& 2) (June-December). 75-86.

340. Kabir, Muhammad Mujibul., Ahmad, Waqar \& Hoque, Rahman, M. Masud. (2006). On predictability of Portfolio Performance. Finance and Banking, 8(1 \& 2) (JuneDecember), 85-90.

341. Kajuter, Peter. (2004). Cost Management: Creaive Value. The Cost \& Management Journal. 32(6) (November-December), 12-15.

342. Kamal, Mohammaed Akhter. (2004). Risk Management. The Bangladesh Accountant, 43(16) (April-June), 81-84.

343. Kamal, Yousuf. (2006). Central Depository System in the security market in Bangladesh. The Cost \& Management Journal, 34(1) (January - February), 515 . 
344. Karim, A. K. M. W. (1997). Users' Information Needs: A Cross-National Study. The Dhaka University Journal of Business Studies, 18(2) (December), 13-47.

345. Karim, Mir Nazmul. (1999). Risk Analysis and its Impact on Corporate health. The Bangladesh Accountant, 27(1) (January - March), 112-118.

346. Khalily, M. A., Baqui, Islam, M., Sadequl. (2003). Capital Market Development in Bangladesh. Journal of the Institute of Bankers, Bangladesh. 50. 2(December).

347. Khan, A. R. (1982). Rural Credit Operations of banks Branches - A Survey Findings. Bank Parikrama, 10(1, 2, 3, \& 4) (March, June, September \& December).

348. Khan, A. R. (1987). Uses and Misuses of Rural Loans of Commercial Bank. The Dhaka University Journal of Business Studies, 8(1) (June), 53-61.

349. Khan, Abdur Rahman. (1994). Role of Nationalized Banks in Mobilization of Rural Savings: A Case study with reference to Janata Bank. The Cost \& Management Journal. 22(2) (March-April), 31-40.

350. Khan, Al Mahruf. (1998). Capital Market Development in Bangladesh: Point to Ponder. The Bangladesh Accountant, 26(4) (October - (December), 119-127.

351. Khan, Al. Maruf. (1996). Valuation of Shares: Aspects on Premium and Revaluation. The Bangladesh Accountant, 24(1) (January - March), 92-96.

352. Khan, Aminul Islam. (1978). Investment Climate in Bangladesh. Journal of the Institute of Bankers, Bangladesh. 8. (December), 5-16.

353. Khan, Azizur Rahman. (1988). Repayment performance \& Factors of Repayment - A Study of Rural Borrowers of Commercial Banks in Bangladesh. The Dhaka University Journal of Business Studies, 9(1) (June), 61-73.

354. Khan, MD. A. R. (1980). Why Institutional Loans are refused to Small Entrepreneurs? An Analysis of Some Rejected Loan Applications. The Dhaka University Journal of Business Studies, 1(2) ((June), 1-7.

355. Khan, MD. Harun-Ar-Rashid \& Howlader, Sushil Ranjan. (1984). Bangladesh Securities Market - Challenge and Prospects. The Dhaka University Journal of Business Studies, 5(2) (December), 121-138.

356. Khan, Md. Hassanul. (1993). Career Development \& Training Needs Assessment of Audit Officials. The Cost \& Management Journal. 21(1) (January - February), 20-22.

357. Khan, Md. Moinuddin. (1991). A Model of Financial Appraisal of a Bank. The Bangladesh Accountant, 18(9) (January - March), 30-35.

358. Khan, Md. Muinuddin. (1991). Evaluation of Finance Performance of an Edible Oil Co. The Cost \& Management Journal, 19(1) (January - February), 5-11.

359. Khan, Md. S. H. \& Shah, A. K. F. H. (2000). Efficiency of Some Selected Commercial Banks in Bangladesh. The Dhaka University Journal of Business Studies, 21(1) (June), 15-29.

360. Khan, Murshid Ali. (1993). Credit Flow After Interest Rate Liberalization: Issue and Problems. Bank Parikrama, 18.

361. Khan, Murshid Kuli. (1992-1995). How Monetary Policy should be made \& conducted, the lessons from USA \& UK. Journal of the Institute of Bankers, Bangladesh. 36 to 41. (December - June), 29-35.

362. Khan, Murshid Kuli. (2003). Anti Money Laundering Measures: A global scenario visà-vis Bangladesh Perspective. The Bangladesh Accountant, 39(12) (January March), 23-29.

363. Khan, Syed Ahmed. 1990-91. Privatization: An evaluation for the Banking sector in Bangladesh. Bank Parikrama, 15-16, 98-113.

364. Khan, Tanvir Ahmed. (2005). Management of Non-performing Loans: An Analysis in the Context of Bangladesh. Bank Parikrama, 30(2) (June). 
365. Khan, Tariqul Islam. (2000). Annual Financial Statements if banking Companies - Are those serving the purpose. The Bangladesh Accountant, 29(2) (April - June), 99-106.

366. Khanam, Begum K. (1981). Budgeting: An Aid to increase Efficiency and Profitability. The Dhaka University Journal of Business Studies, 2(2), 65-73.

367. Khanam, Begum K. (1995). Lease Financing Practices in Bangladesh: A case Study of IDLC. The Dhaka University Journal of Business Studies, 16(2) (December), 225-237.

368. Khondokar, Mubina, Rahman, Md. Masudur. (1993). Trends in Financial Indicators of Insurance Industry: A Case Study. The Cost \& Management Journal. 21(6) (November-December), 24-27.

369. Khondoker, Md. Ziaul Hauqe. (1992). Privatization and Capital Market with reference to Bangladesh. Bank Parikrama, 17.

370. Kumar, B. R. (2002). Application of Capital Asset Pricing Model (CAPM) in DSE of Bangladesh. Business Review, 3(1) (June), 92-100.

371. Lalarukh, Farzana \& Amin, Shabnaz. (2006). Performance of Behavior of DSE20 Index. Journal of Business Studies, 27(2) (December), 345-372.

372. Liakat, Md., Moral, Hossn. (1996). Problems of Leading Risk Analysis. Journal of the Institute of Bankers, Bangladesh. 43. (June), 64-72.

373. Libby, Theresa \& Lindsay, R. Murray. (2005). Budgeting - An Unnecessary Evil. The Cost \& Management Journal, 33(2) (March - April), 9-12.

374. Loqman, Muhammad. (1992). Financial Analysis of Accounting Data - A Study of Jute and Cotton Industries in Bangladesh. The Cost \& Management Journal. 20(5) (September - October), 28-36.

375. Lorino, Philippe. (1997). Target Costing: Toolbox or organizational Learning process? The Cost \& Management Journal. 25(2) (March - April), 17-27.

376. Mahmud, Khalid. (1980). Mathematical Programming Model For Cash-Flow Estimation of Complex Industrial Production System. The Journal of Management Business \& Economics, 6(2) (April).

377. Mahmud, Parveen. (2003). Corporate Social Responsibility in Developing Countries. The Bangladesh Accountant, 41(14) (July - September), 4-12.

378. Mahtabuddin, Khondokar, A. A. (1983). Employment of Bank's Fund. Bank Parikrama, $6(3 \& 4)$ (September \& December).

379. Majid, M. A. (1983). Role of Bank Credit in Rural Development. Journal of the Institute of Bankers, Bangladesh. 17. (June), 38-48.

380. Majumder, Hari Narayan. (1998). Problems and Prospects of Re-orienting Commercial Banks to Microfinance in Bangladesh. Bank Parikrama, 23(September \& December), 85-95.

381. Majumder, M. Abul Kalam. (1988). The Stock market growth continues. The Cost \& Management Journal. 16(1) (January - February), 38-39.

382. Malek, Moniruzzaman. (2005). A Comparative Analysis of Commercial Banking Performance in Bangladesh. The Cost \& Management Journal, 33(3) (MayJune), 29-33.

383. Mallick, Ali Ahmed. (1993). Investment in Bangladesh: 1980- (1991). The Jahangirnagar Economic Review. 8(1) (June), 94-100.

384. Mallick, Ali Ahmed. (2002). Capital Investment Decision as based on NPV rule: A discussion. The Jahangirnagar Economic Review. 13(1) (June), 57-66.

385. Mallick, Ali Ahmed. (2004). Minimum Variance Opportunity Set (MVOS) and Portfolio Decision. Journal of Business Research, 6, 41-64. 
386. Mamun, Ashraf Al. (2002). Corporate Governance in Japan: Lessons for Bangladesh. Bank Parikrama, 27(2 \& 3) (June \& September).

387. Mamun, Md. Z \& Rahman, Ahsan Adehar. (2002). Performance Evaluation of the Private Lie Insurance Companies of Bangladesh: A Private-Public Comparison. Journal of Business Administration, 28(1 \& 2) (January \& April).

388. Mamun, Mohammed Abdullah. (1992). Earning Asset Management in the Nationalized Commercial Banks of Bangladesh. The Cost \& Management Journal. 20(6) (November-December), 37-45.

389. Maola, Syed Golam. (1994). Motivation of the Bangladeshi Partners for Investment in International Joint Ventures: An Empirical Study. Journal of Business Administration, 20(1 \& 2) (January \& April).

390. Maola, Syed Golam. (1998). Dynamics of Firm Sizes and the Return on Investment of the Foreign Joint Ventures in Bangladesh. Journal of Business Administration, 24(1 \& 2) (January \& April).

391. Mazid, A. K. M. Abdul \& Saha, Arabinda. (1998). Performance Evaluation of Commercial Banks in Bangladesh: A Diagnostic Review. The Cost \& Management Journal, 26(6) (November-December), 31-34.

392. Mia, Md. Abdul Hannan \& Al-Mamun, Md. (2003). Is Beta the Panacea of Security Valuation? The Cost \& Management Journal, 31(3) (May -June), 13-19.

393. Mia, Md. Abdul Hannan \& Al-Mamun, Md. (2005). (September-October). Can Behavioral Finance Rationalize the Sources of Alpha? The Cost \& Management Journal, 33(5) (September - October), 6-16.

394. Miah, M. U. Ali. (1980). Budget and Budgetary Control in Bangladesh Industrial Enterprise. The Cost \& Management Journal. 8(2 \& 3) (July - September), 2528.

395. Mina, M. S. (1982). Institutional Credit for Housing Finance. The Dhaka University Journal of Business Studies, 3(2) (December), 35-44.

396. Mina, Md. S \& Taleb, Md. A. (1995). Financial Diagnosis: A Case Study. The Dhaka University Journal of Business Studies, 16(2) (December), 43-65.

397. Mina, Md. S. (1983). Urban Housing Situation and Need for Mortgage Financing in Bangladesh. The Dhaka University Journal of Business Studies, 4(1) (June), 113-122.

398. Mina, Md. Shahjahan. (1980). Involvement of banking Sector in Rural Development of Bangladesh. Bank Parikrama, 5(1 \& 2) (March \& June).

399. Mish, Md. Uttam Ali. (1981). Financial Profitability and Losses in Public Enterprises in Bangladesh. The Cost \& Management Journal. 9(4) (October-December), 3742.

400. Misir, Mohammad A. (1998). Approaches to the Liquidity Management of Commercial Banks: A Critical Review. The Dhaka University Journal of Business Studies, 19(2) (December), 275-291.

401. Misir, Mohammad A. (2003). Growth Pattern of Securities Market in Bangladesh. Journal of Business Studies, 24(1) (June), 137-152.

402. Mobarek, A. \& Mollah, Abdus S. (2002). Dividend Policy/Behaviour: Critical Analysis of the Prior: Theories and Empirical Evidence. Journal of Business Studies, 23(2) (December), 233-254.

403. Mobarek, A. \& Mollah, Abdus S. (2002). Weak Form Market Efficiency: Review of Prior Empirical Evidence. Journal of Business Studies, 23(2) (December), 269-284. 
404. Mohiuddin, K. M. Golam, Salahuddin Ahmad. (1997). Some Aspects of Financial Management of Small Manufacturing Enterprises in Bangladesh. The Cost \& Management Journal. 25(6) (November-December), 15-17.

405. Mohiuddin, Md \& Najibullah, Syed \& Shahid, Abdullah Ibney. (2006). An Exploratory Study on Intellectual Capital Performance of the Commercial Banks in Bangladesh. The Cost \& Management Journal, 34(6) (November-December), 40-54.

406. Mohiuddin, Md. (1977). Capital Investment Decision. The Bangladesh Accountant, 2(2) (November), 5-9.

407. Mohiuddin, Md. (1983). Cash Budget - An effective means to solve liquidity problems. The Cost \& Management Journal. 11(1) (January - February), 21-26.

408. Moldrich, D, Jayavarman, S. (1995). Capital Market Development: Sri Lankan Experience. The Bangladesh Accountant, 23(3) (July-September), 99-104.

409. Mollah, A. Sabur, Rahman, Md. Zahedur \& Islam, Md. Saiful. (2005). Return Behavior of the DSE-20: An Empirical Investigation on the Dhaka Stock Exchange. Journal of Business Studies, 26(2) (December), 152-160.

410. Mollha, A. S \& Jamil, Gazi Md. Hasan. (2003). Multifactor Explanations of CAPM in Dhaka Stock Exchange. Journal of Business Administration, 29(3 \& 4) (July \& October).

411. Mollha, A. S \& Mobarek, Asma \& Islam, Md. Saiful. (2006). Day-of-the week-effect of the Dhaka Stock Exchange: Evidence from the GARCH Model. Journal of Business Administration, 32, (1 \& 2) (January \& April), 71-83.

412. Mollik, Abu. Taheer. (2002). Market Efficiency and mean- Reversion in the Stock Prices: Australian Evidence. Rajshahi University Studies, 10, 129-140.

413. Momen, Md. A. \& Khan, Shmed S. (1989). An Evaluation of I. C. B unit Fund - As a toll for small savings utilization in Bangldesh. Journal of Business Administration, $15(3 \& 4)$ (July \& October).

414. Momen, Md. A. \& Rahman, Sayma. (2006). Effect of Market Stock Index, Interest Rate and Gold Price on Gold Stock Price-An Australian Case using Co integration Approach. Journal of Business Studies, 27(1) (June), 203-212.

415. Momen, Md. Abdul \& Amin, Abu Saleh Md. Muntasir. (2005). Does Long-Run Purchasing Power Parity Hold? Journal of Business Administration, 31(3 \& 4) (July \& October), 1-14.

416. Momin, Mahmood Ahmed, Ali, Md. Shahjahan. (1995). Liquidity Management in Public Enterprises: A Casestudy of the Sugar Mills Under BSFIC. The Cost \& Management Journal. 23(2) (March - April), 32-35.

417. Moniruzzaman, M., Rahman, Md. Sydur. (1990-1991). Profitability Performance of Denationalized Banks - A Comparative Study of the Pre and Post Denationalization Periods. Bank Parikrama, 15-16.

418. Morium, Sharmin. (2002). Measuring Business Performance in the Banking Sector: Balanced Scorecard Approach. Bank Parikrama, 27(2 \& 3) (June \& September).

419. Mufti, Qaisar. (1996). Debt Equity Ratio. The Bangladesh Accountant, 24(1) (January March), 97-100.

420. Muhiuddin, K. M. Golam, Islam Md. Ayub. (1993). Application of Quantitative Models in Inventory Planning - A Study on Public and Private sector manufacturing. The Cost \& Management Journal. 21(4) (July - August), 25-29.

421. Muhiuddin, K. M. Golam, Jahur, Md. Saleh. (1992). Cost-Volume-Profit Analysis - A Case Study in a Selected Enterprise Under Bangladesh Chemical Industries Corporation. The Cost \& Management Journal. 20(2) (March-April), 21-26. 
422. Muhuuddin, K. M. (1993). Impact of Institutional Holdings on the performance of American Corporations and its relevance to Bangladesh. The Cost \& Management Journal. 21(5) (September - October), 9-11.

423. Munira, S. (2003). Determinants of Credit Risk of Housing Loan-The Case of Delta BRAC Housing Finance Corporation. Journal of Business Studies, 24(1) (June), 67-75.

424. Muqtader, A. N. M Abdul. (1988). Inventory Control through Ratio Analysis. The Cost \& Management Journal. 16(4) (July - August), 19-22.

425. Murshed, A. J. M. H. (1989). Biasing in Budgetary Planning. The Dhaka University Journal of Business Studies, 10(2) (December), 145-158.

426. Musa, Mohammad., Morshed, Mokhdum \& Faruqui, Golam Ahmed. (2006). The Behavior of Short-Term Returns of large Capitalization Stocks, Traded in Bangladesh Stock Exchanges. Journal of Business Administration, 32(1 \& 2) (January \& April), 43-68.

427. Nizami, Md. Helal Uddin. (1991). Role of Bangladesh Shilpa Bank in Financing Industrial Project. The Cost \& Management Journal, 19(1) (January February), 12-16.

428. Omar-Al-Farooque, M. (1998). The Economic Role of the Japanese 'Main Bank' System. The Dhaka University Journal of Business Studies, 19(2) (December), 175-202.

429. Paramanik, Md. Abaydur Rahman. (1985). The Efficient market hypothesis and the quality of accounting information. The Cost \& Management Journal. 13(4) (July-August), 22-24.

430. Plenderleith, Mr. Ian. (2002). What is new in the financial markets in the UK. The Bangladesh Accountant, 38(11) (October - (December), 146-152.

431. Purohit, Kanchan Kumar \& Mazumder, Bidhan Chadra. (2006). Performance Measurement of Banks: An Application of Balanced Scorecard. The Cost \& Management Journal, 34(6) (November-December), 21-30.

432. Purohit, Kanchan Kumar, Uddin, Md. Salim. (1995). Behavior of cost structure: A Study on Fertilizer companies in Bangladesh. The Cost \& Management Journal. 23(6) (November-December), 7-12.

433. Purohit, Kanchan Kumar., Chandra, Bidhan \& Mazumder. (2005). Credit Rating in Bangladesh - An Overview. The Cost \& Management Journal, 33(5) (September - October), 62-72.

434. Quader, Md. Tarique, Hai, Md. Abdul. (2004). Impact of Cash Incentive Scheme of Bangladesh Government on Export Promotion: An Assessment. The Cost \& Management Journal. 32(6) (November-December), 22-31.

435. Quader, Md. Tarique, Hai, Md. Abdul. (2004). Measurement of Trends and Productivity of Grameen Bank. The Cost \& Management Journal. 32(4) (July - August), 24-27.

436. Quadir, S. M. Nasrul \& Jahur, Md. Saleh. (2001). Determinants of Financial Performance of Textile and Clothing Industry: An Application of Multiple Discrimination Analysis. Journal of Business Administration, 27(1 \& 2) (January \& April).

437. Quayyum, Nazmul. (1990). Financial Management Practices in a Multinational Company in Bangladesh - A Case Study. The Cost \& Management Journal. 18(1) (January - February), 30-35.

438. Quayyum, Nazmul. (1991). Business Failure in Bangladesh. The Bangladesh Accountant, 18(9) (January - March), 46-52. 
439. Qureshi, A. A. (1989). Innovations in Financial Intermediation in the Banks in Post Liberation Period. Bank Parikrama, 14.

440. Qyader, Md Tarique, Hai, Md. Abdul. (2003-2004). Lending risk Minimization of microfinance programmes. The Bangladesh Accountant, 42(15) (OctoberMarch), 109-113.

441. Rahman, A. K. M. (1978). Small Loan Scheme and its Operations. Bank Parikrama, 3(1) (March), 54-60.

442. Rahman, A. Z. m Anisur, Khanam, Begum Khaleda. (1996). Working Capital Management - A Study on mehar Industries Bangladesh Ltd. The Cost \& Management Journal. 24(3) (May - June), 5-12.

443. Rahman, A. Z. M Anisur. (1986). Capital Budgeting - Evaluation Methods Under Certainty. The Cost \& Management Journal. 14(1) (January - February), 1523.

444. Rahman, A. Z. M. Anisur. (1986). Commodity Exchange and Investment in Futures Markets. The Cost \& Management Journal. 14(3) (May-June), 11-16.

445. Rahman, A. Z. M. Anisur. (1992). Capital Asset Pricing Model - A Way of Calculating cost of Equity. The Cost \& Management Journal. 20(6) (NovemberDecember), 6-8.

446. Rahman, M Hafizur \& Haque, Md. Minimal \& Rahman, Swapnil. (2004). Growth Trend of Public Issue of Listed Securities in the Stock Market Development of Bangladesh: Evidence from Dhaka Stock Exchange Ltd. Business Review, 4(1 \& 2) (December), 48-54.

447. Rahman, M. \& Sarker, Md. M. R. (1998). The Asian Financial Crisis: Genesis and Implications. The Dhaka University Journal of Business Studies, 19(2) (December), 1-29.

448. Rahman, M. Lutfor. (1982). Some Aspects of Financing Small Farmers in Bangladesh. Bank Parikrama, 7(1 \& 2) (March \& June).

449. Rahman, M. Mozibor. (1992). Development of Capital Market and Economic growth: Role of Investment Finance Institutions. Bank Parikrama, 17, 21-23.

450. Rahman, M. Zubaidur. (1985). Transfer Pricing in Multinational Enterprises. The Journal of Management Business \& Economics, 11(2) (April).

451. Rahman, Mahmudur. (1996). Use of Learning Curve in Predicting Cost- Its Definition, Theories and Applications. Business Review, 2 (1), 48-53.

452. Rahman, Md Anisur., Uddin, Mohammad Riaz \& Malik, Mafuza. (2006). Structured Analysis of Operational System: A Case Study on Dhaka Stock Exchange (DSE) Limited. The Cost \& Management Journal, 34(2) (March - April).

453. Rahman, Md. Abdur, Muttakin, Md. Badrul. (2000). Profitability of Private Sector general insurance companies in Bangladesh. The Bangladesh Accountant, 29(2) (April - June), 107-110.

454. Rahman, Md. H. \& Talukder, Abu S. (1995). Assessing Market Efficiency: A Time Series Approach. The Dhaka University Journal of Business Studies, 16(2) (December), 165-174.

455. Rahman, Md. Habibur. (1998). Economics in Islamic Framework: An Evaluation. The Cost \& Management Journal, 26(6) (November-December), 18-23.

456. Rahman, Md. Hafizur. (2001). Productivity Performance Evaluation of Investment Corporation of Bangladesh: A Case Study. Rajshahi University Studies, 9, 8597.

457. Rahman, Md. M. (1999). The Extent of Mandatory and Voluntary Financial Disclosure by Listed Companies in Bangladesh: An Empirical Study. The Dhaka University Journal of Business Studies, 20(1) (June), 189-208. 
458. Rahman, Md. Maksudur. (1998). The Asian Financial Crisis: A Fundamental Flaw in the Asian Economy. The Cost \& Management Journal, 26(6) (NovemberDecember), 11-17.

459. Rahman, Md. Masudur \& Muzareba, Abureza Mohammad. (2005). Personal Loan of Local and Foreign Bank: A Success Story- but a Sustainable Strategic Adaptation is still A Challenge. Finance and Banking, 7(1 \& 2) (JuneDecember), 87-104.

460. Rahman, Md. Matiar. (2004). Growth Trend, Profitability and Productivity of the BASIC Bank limited: A Multivariate Analysis. The Bangladesh Accountant, 44(14) (July-September), 16-22.

461. Rahman, Md. Mujibur. (1999). Development of Financial Services and Accounting Profession. The Cost \& Management Journal, 27(6) (November-December), 17-20.

462. Rahman, Md. Saidur. (1996). Financial Statement Analysis for Bank Lending. Some issues and considerations. Journal of the Institute of Bankers, Bangladesh. 43. (June), 73-98.

463. Rahman, Md. Saidur. (1997). Profitability in Banks: An Empirical Study on Portfolio Management and Macroeconomic Variables in Bangladesh. Bank Parikrama, 22(2) (June).

464. Rahman, Md. Shamsur. (1976). Some Problems of Agricultural Credits in Bangladesh. Journal of the Institute of Bankers, Bangladesh. 3. (June), 7-12.

465. Rahman, Shofqur \& Hossain, Md. Farhad. (2006). Weak Form Efficiency: Testimony of Dhaka Stock Exchange. Journal of Business Research, 8(June), 1-12.

466. Rahman, Sk. F. (1979). Inventory Problems and practices-A study of some Nationalized Industrial units of Rajshahi Region. The Dhaka University Journal of Business Studies, 1 (1) (December), 65-77.

467. Rahman. M. M. (1989). Financial Management of Public Sector Enterprises: A Case of BCIC. The Dhaka University Journal of Business Studies, 10(2) (December), 123-134.

468. Raqib, Abdur. (1983). Credit for Equitable Rural Development in Bangladesh. Bank Parikrama, 6(3 \& 4) (September \& December).

469. Raqib, Abdur. (1991-1992). Agricultural Loan Recovery Problem in Bangladesh. Journal of the Institute of Bankers, Bangladesh. 34 \& 35. (December - June), 2-26.

470. Raqib, Abdur. (1993). Decade of private Banking in Bangladesh. Bank Parikrama. Bank Parikrama, 18 ( $1 \&$ 2), (March \& June), 64-69.

471. Rashid, Md. A. (1994). Financial Sector Liberalization in Bangladesh - The Impact of Interest Rate Flexibility. Journal of Business Administration, 20(1 \& 2) (January \& April).

472. Rashid, Md. Abdur Rashid. (1985). An Analytical view of Dhaka Stock Exchange. The Cost \& Management Journal. 13(1) (January - February), 13-22.

473. Rashid, Mohammad Mamdudur. (1995). Emergence of Securities Market in China. Bank Parikrama, 20 (1 \& 2) (March \& June).

474. Robbani, Md. Golam. (1995). Liquidity Analysis through Ratios: A case study of M/S Granery Bakery of BSCIC Industrial estate, Rajshahi. Rajshahi University Studies, 3, 81-98.

475. Roberts. (1998). Analysis of Organizational Performance Utilizing Multivariate Analysis - A Literature Review. Journal of Business Administration, 24 (3 \& 4) (July \& October). 
476. Roy, Dilip Kumar \& Tipy, Mansur Alam. (2006). Domestic Debt Situation in Bangladesh: An Exploratory Review. Journal of Business Administration, 32(4) (July \& October), 105-130.

477. Roy, Kazal Kumar. (1987). Sensitivity Analysis - A Decision Making Tool. The Cost \& Management Journal. 15(3) (March - June), 23-28.

478. Roy, Mohan L., Akhter, Ireen \& Kabir, Shariar. (2006). The environment of corporate financial reporting system in Bangladesh - A critical Evaluation. Journal of Business Research, 8(June), 77-90.

479. Rubayat-ul-Islam, S. \& Arefin, K. \& Saha Nilanjan K. (1999). A Proposal to Introduce Collective Credit and Insurance in Bangladesh. The Dhaka University Journal of Business Studies, 20(2) (December), 235-250.

480. Sadique, M. Shibley \& Chowdhury, Shah Saeed Hassan. (2001). Linear Causal Relationship between Changes in Stock Price and Trading Volume: The Case of The DSE. Rajshahi University Studies, 9, 13-25.

481. Saeed, Khawaja Amjad. (1990). Lease Financing - Legal and Taxation issues. The Bangladesh Accountant, 16(7) (July - September), 54-57.

482. Saeed, Khawaja Amjad. (2001). Engineering Trends in Global Financial Management. The Cost \& Management Journal, 29(1) (January - February), 7-12.

483. Sah, M. K. Subramania. (1988). Quality Control Costs in Textile Industry. The Cost \& Management Journal. 16(4) (July - August), 23-26.

484. Saha, A. C, Harun, Md. Abdullah A. (1990). Some Aspects of Financial Structure of the Sugar Industry in Bangladesh. The Cost \& Management Journal. 18(4) (JulyAugust), 11-15.

485. Saha, A. C. (1983). An Analytical View of liquidity Management in the Selected Jute Mills of Dhaka Zone. Bank Parikrama, 8(3 \& 4) (September \& December).

486. Saha, A. C. (1983). Working Capital Norms - Tandon Study Group. The Cost \& Management Journal. 11(4) (July - August), 35-38.

487. Saha, Abhinaya C. (1985). Working Capital: A Management Approach. The Cost \& Management Journal. 13(4) (July-August), 35-38.

488. Saha, Abhinaya C. (1986). Some Thoughts on Inventory Management in Rajshahi Silk Factory. The Cost \& Management Journal. 14(6) (November-December), 1824.

489. Saha, Abhinaya Ch. (1984). Some thoughts on efficiency of working capital utilization in Rajshahi Jute Mills during 1979-80 to 1981-82. The Cost \& Management Journal. 12(3) (May - June), 27-30.

490. Saha, Bandana, Habib, Shah Md. Ahsan. (1998). Commercial Bank's Involvement in Micro Finance: Experience of Bangladesh and other Asian Countries. Bank Parikrama, 23(September \& December), 54-84.

491. Saha, Sujit Ranjan. (1996). Ancillary Business and Profitability of Banks: Trends and Prospects. Bank Parikrama, 21(1 \& 2) (March \& June).

492. Saha, Sujit, Rahman, Md. Saidur. (2000). Financial Reporting Practices in Banks \& Financial Institutions: Implementing the New Formats of Financial Statements in Compliance with IAS-30. The Bangladesh Accountant, 30(3) (July September), 11-27.

493. Saha, Sujit. (1980), Introducing Performance Budgeting in the Banking Sector of Bangladesh. Bank Parikrama, 5(3 \& 4) (September \& December).

494. Saha, Sujit., Rahman, Md. Saidur \& Alam, Md. Mossaddake-Ul. (2001). An Evaluation of LRA Practices in Banks in Bangladesh. Bank Parikrama, 26(2) (June). 
495. Saleh, Md. A. (1989). Possibility of Non-Interest Based Banking in Bangladesh with Reference to Arab Middle East. The Dhaka University Journal of Business Studies, 10(1) (June), 9-24.

496. Saleh, Md. Abdu. (1988). Negotiation Skills for Business Executives. The Cost \& Management Journal. 16(5) (September - October), 14-18.

497. Saleh, Md. Abu. (1989). Source of Finance for international Operations: Special Reference to Euro Source. The Cost \& Management Journal, 17(6) (November-December), 31-36.

498. Saleh, Md. Abu. (1989). Source of Financing for International Operations: Special reference to Euro-Source. The Bangladesh Accountant, 12(3) (July September), 52-60.

499. Sarder, Jahangir H. (1996). The impact of Support Services on the Performance of small manufacturing Enterprise in Bangladesh. Journal of Business Administration, 24(3 \& 4) (July \& October).

500. Sarkar, Lutfar Rahman. (1997). Contemporary Issues on Banking. Bank Parikrama, 22(2) (June).

501. Sarker, Maksudur Rahman. (2003). The impact of Financial Instruments on Ownership and Risk Return in venture Capital Investment. The AIUB Journal of Business and Economics, 1(3) (January), 66-81.

502. Sarker, Md. Abdus Samad, Rafiq, Ahmed Istiaque Bin. (1998-2000). Export Credit in Bangladesh. Journal of the Institute of Bankers, Bangladesh. 47. (June December), 121-142.

503. Sarker, Md. M R. (2000). Distribution of Ownership and Value of Option under Staged Financing in Venture Capital Investment. The Dhaka University Journal of Business Studies, 21(1) (June), 121-131.

504. Sarker, Md. Maksudur Rahman, Hossain C. M. Sarowar. (1997). Valuation of Shares in Capital Market of Bangladesh - A Study on Market Perspectve. The Cost \& Management Journal. 25(2) (March - April), 5-10.

505. Sarker, Md. Maksudur Rahman. (2000). A Critical Review of Research on Venture Capital. The Cost \& Management Journal, 28(6) (November-December), 2428.

506. Sarker, Md. Maksudur Rahman. (2000). Economic Value Added: A New Technique in Corporate Performance Measurement. The Cost \& Management Journal, 28(1) (January - February), 7-9.

507. Sayaduzzaman, Md. Hossain, Syed. (2000). Planning and Control of Financial Structure of the Sugar Industry in Bangladesh: An Evaluation. The Bangladesh Accountant, 31(4) (October - (December), 55-62.

508. Sayeed, Md. Abu \& Aziza, Tasnima. (2006). Relationship of Deposit growth with cost of deposit and ROE: A Study on private commercial Banks. Journal of Business Research, 8(June), 23-32.

509. Sen, Dilip Kumar. (2006). An Agenda for a Research Study on the Interface of Some Frontier Issues of Accounting, Economics and Finance in the Perspective of SAARC Nations. Journal of Business Studies, 27(1) (June), 203-212.

510. Shah, Saroj K. (1980). Performance Criteria for Public Sector of Bangladesh. The Dhaka University Journal of Business Studies, 1(2) (June), 27-36.

511. Shahid, A. T. M. Abdus, Banerjee, Prashanto K. \& Mamun. (2003 \& 2004). Innovation in Banking Products in Bangladesh. Bank Parikrama, (28 \& 29) (June \& December).

512. Sidat, Ibrahim. (2003). Corporate governance: A Regulatory imposition or A Business Imperative. The Bangladesh Accountant, 39(12) (January - March), 63-66. 
513. Siddique, Shafiq Ahmed. (1986). Depreciation in the context of Investment Policy. The Dhaka University Journal of Business Studies. 7(1) (June), 77-87.

514. Siddique, Shafique A. (1986). Various Tax-Depreciation methods and their influence On Investment Decision - A Comparative Analysis. The Dhaka University Journal of Business Studies, 7(2) (December), 73-83.

515. Siddique, Sharif Rayhan \& Islam, A. F. M Mafizul. (2001). Banking in Bangladesh: its contribution and Performance. Journal of Business Research, 3, 63-73.

516. Siddique, Sharif Rayhan. (1997). Impact of Share Valuation in Stock Market: The Example of Bangladesh. Journal of Business Administration, 23(1 \& 2) (January \& April).

517. Sil, Subhash Chandra. (2001). Approaches to Working Capital Financing their Relevance to Risk and Return. Rajshahi University Studies, 9, 1-12.

518. Sinclair, Kenneth P, James A. Talbott, Jr. (1988). Using Breakeven Analysis when Cost Behavior is Unknown. The Cost \& Management Journal. 16(3) (May - June), 20-23.

519. Singhal, Deepjee A. \& Pipalia, Manish I. (2003). Business Risk Management. The Cost \& Management Journal, 31(2) (March - April), 19-22.

520. Solaiman, Md, Bellal, Ataur, Rahman. (1995). Financing of working Capital in Public Sector jute manufacturing enterprises in Bangladesh: An emperical Analysis. The Cost \& Management Journal. 23(3) (May - June), 19-22.

521. Solaiman, Mohammed \& Kamal, Mohammed Mostafa. (2006). Credit Management: An Evaluation of the Nationalized Commercial Banks of Bangladesh. The Cost \& Management Journal, 34(1) (January - February), 29-45.

522. Solaiman, Mohammed. (1991). Insight in to the Performance of Public Sector Enterprise. The Bangladesh Accountant, 18(9) (January - March), 42-45.

523. Taheruddin, Muhammad. (1992). Financial Liberalization. Bank Parikrama, 17.

524. Taheruddin, Muhammad. (1993). Aspects of Portfolio Management in Banks in Bangladesh. Bank Parikrama, 18.

525. Taleb, M. A. (1995). Financial planning of Rajshahi Textile Mills- A Case Study. Rajshahi University Studies, 3, 13-26.

526. Toby, Adolphus J. (1993). Further Empiricism on the Miller-Orr Cash Model. Journal of Business Administration, 19(3 \& 4) (July \& October).

527. Udddin, Md. Hamid. (1997). Wealth Redistribution and Stockholders-Bondholders Conflict: A Brief Review of Theory and Empirical Evidences. Journal of Business Administration, 23(1 \& 2) (January \& April).

528. Udddin, Md. Hamid. (2003). Aftermarket Performance of Malaysian IPOs: An Empirical Analysis. Journal of Business Administration, 29(1 \& 2) (January \& April).

529. Udddin, Md. S. (1986). A Structural Analysis of Monetary Policy in Bangladesh: 197381. The Journal of Management Business \& Economics, 12(1) (January).

530. Uddin, Md. Akhtar. (1995). Rural Financing by Rajshahi Krishi Unnayan Bank: A Case Study of Puthia Branch. The Cost \& Management Journal. 23(4) (July August), 22-25.

531. Uddin, Md. H. (2001). Dividend Effects and Shareholders' Value: A brief Review of Research Literature on Dividend Effects. Journal of Business Studies, 22(2) (December), 237-248.

532. Uddin, Md. Hamid \& Chowdhury, Golam Mohammed. (2005). Effect of Dividend Announcement on shareholders' value: Evidence from Dhaka Stock Exchange. Journal of Business Research, 7(June), 61-77. 
533. Uddin, Md. Hamid, Hossain, Md. Zakir \& Abdullah, Abu. Md. Y. (2004). An Empirical Study on Capital Structure of the Companies Listed on the Dhaka Stock Exchange. Journal of Business Administration, 30(1 \& 2) (January \& April).

534. Uddin, Md. Hamid, Mohiuddin, Md. (2004), The effect of Dual Listing Announcement on Shareholders' Value: Evidence from DSE. The AIUB Journal of Business and Economics, 3(2) (August), 83-92.

535. Uddin, Md. Hamid. (2001). Why do IPO Investors Earn High Initial Return on Stock Listing Day?. Journal of Business Administration, 27(3 \& 4) (July \& October).

536. Uddin, Md. Salim, Das, Shanti Ranjan. (1996). Cash Flow Performance of selected Manufacturing Enterprises of Chittagong. The Cost \& Management Journal. 24(2) (March - April), 7-12.

537. Uddin, Md. Salim, Quadir, S. M. Nasrul. (1998). Nationalization and Denationalization of Commercial Banks in Bangladesh: A Comparative study of performance. Bank Parikrama, 23(September \& December), 5-25.

538. Uddin, Md. Salim., Uddin, Md. Mohi \& Ahmed, Sharmeen. (1999). Disclosure of Social Performance in the Corporate Reports of Bangladesh. The Cost \& Management Journal, 27(1) (January - February), 18-22.

539. Uddin, Mohammad Riaz., Iqbal, Mohammed Masum \& Reza, Syed Maruf. (2006). Disclosure Practices: A Comparison of commercial Banks and Insurance Companies in Bangladesh. The Cost \& Management Journal, 34(1) (January February), 16-28.

540. Uddin, Mohammad Sohrab. (1984). Monetary and Credit programming in Bangladesh. Bank Parikrama, 9(3 \& 4) (September \& December).

541. Uddin, Mohammad Sohrab., Saha, Bandana, Choudhury, Toufic Ahmad. (1985). Growth and Structure of the Banking Sector in Bangladesh. Bank Parikrama, $10(1,2,3, \& 4)$.

542. Uddin, Nasir \& Islam, Farzana. (2003). The Portfolio Management of Commercial Banks of Bangladesh: An Evaluation. The Cost \& Management Journal, 31(1) (January - February), 18-24.

543. Uddin, Nasir. (2001). Commercial Banks of Bangladesh - A Rating. The Cost \& Management Journal, 29(2) (March - April), 30-36.

544. Uddin, Shahzad Nasir. (1993). Capital Structure and its Relevant Issues: A Case Study of Pharmaceuticals Industries Listed on Dhaka Stock Exchange. The Cost \& Management Journal. 21(2) (March - April), 19-23.

545. Werner, Wendy. (2003). Corporate Governance: The role of accountants. The Bangladesh Accountant, 39(12) (January - March), 42-62.

546. Wilson, Jim, Ervin, Michael. (1998). The CFO's Role in Corporate Governance. The Cost \& Management Journal. 26(4) (July - August), 12-14.

547. Younus, Sayera. (2003 \& 2004). The Impact of Monetary Policy on the Bank Portfolio in Bangladesh. Bank Parikrama, 28 \& 29(June \& December).

548. Zahid, Jawader Rahim. (1998). Capital Asset Pricing Model (CAPM): Is it Dead?. Journal of Business Administration, 24, (1 \& 2) (January \& April).

549. Zaman, Jamshed uz \& Bakshi, Barun Krishna. (1999). The Exchange Rate Determination in Bangladesh-Does Purchasing Power Parity Hold: A Cointegration Approach. Journal of Business Research, 2, 37-42. 
Table 1: List of finance relevant available journals in Bangladesh with publishers

\begin{tabular}{|c|c|c|c|}
\hline Sl. & Publisher of Journal & Department/Institution & Name of the Journal \\
\hline 1 & $\begin{array}{l}\text { American International } \\
\text { University-Bangladesh }\end{array}$ & & $\begin{array}{l}\text { The AIUB Journal of Business and } \\
\text { Economics }\end{array}$ \\
\hline 2 & $\begin{array}{l}\text { Bangladesh Institute of Bank } \\
\text { Management }\end{array}$ & & Bank Parikrama \\
\hline 3 & Bangladesh Open University & & Journal of Business studies \\
\hline 4 & Chittagong University & Faculty of Business & Journal of Business \\
\hline 5 & $\begin{array}{l}\text { Daffodil International } \\
\text { University }\end{array}$ & & $\begin{array}{l}\text { Daffodil International University } \\
\text { Journal of Business and Economics }\end{array}$ \\
\hline 6 & Jahangirnagar University & $\begin{array}{l}\text { Department of Business } \\
\text { Administration }\end{array}$ & Journal of Business Research \\
\hline 7 & Jahangirnagar University & Department of Economics & The Jahangirnagar Economic Review \\
\hline 8 & Jahangirnagar University & Social Science Faculty & The Jahangirnagar Review \\
\hline 9 & Khulna University & Business School & Business Review \\
\hline 10 & North South University & & $\begin{array}{l}\text { North South University Business } \\
\text { Review }\end{array}$ \\
\hline 11 & Rajshahi University & Faculty of Business & Rajshahi University Studies \\
\hline 12 & South East University & & Journal of Business studies \\
\hline 13 & $\begin{array}{l}\text { The Institute of Bankers, } \\
\text { Bangladesh }\end{array}$ & & $\begin{array}{l}\text { Journal of the Institute of Bankers, } \\
\text { Bangladesh }\end{array}$ \\
\hline 14 & $\begin{array}{l}\text { The Institute of Chartered } \\
\text { Accountants of Bangladesh }\end{array}$ & & The Bangladesh Accountant \\
\hline 15 & $\begin{array}{l}\text { The Institute of Cost and } \\
\text { Management Accountant of } \\
\text { Bangladesh }\end{array}$ & & The Cost \& Management Journal \\
\hline 16 & University of Dhaka & $\begin{array}{l}\text { Institute of Business } \\
\text { Administration }\end{array}$ & $\begin{array}{l}\text { Journal of Business Administration, } \\
\text { and Journal of Management } \\
\text { Business \& Economics }\end{array}$ \\
\hline
\end{tabular}




\begin{tabular}{|r|l|l|l|}
17 & University of Dhaka & Faculty of Business & $\begin{array}{l}\text { The Dhaka University Journal of } \\
\text { Business Studies }\end{array}$ \\
\hline 18 & University of Dhaka & Department of Finance & Finance and Banking \\
\hline 19 & University of Dhaka & Department of Marketing & Journal of Marketing \\
\hline 20 & University of Dhaka & Department of Management & Journal of Management \\
\hline
\end{tabular}

Table 2: List of finance relevant research publishers, journal publication starting year and number of publications in finance related areas in Bangladesh

\begin{tabular}{|l|c|c|}
\hline \multicolumn{1}{|c|}{ Name of Publishers } & $\begin{array}{c}\text { Publication } \\
\text { Starting } \\
\text { Year }\end{array}$ & $\begin{array}{c}\text { No. of } \\
\text { Finance } \\
\text { Papers }\end{array}$ \\
\hline Institute of Chartered Accountants Bangladesh (ICAB) & 1973 & 53 \\
\hline Institute of Cost and Management Accountant of Bangladesh (ICMAB) & 1973 & 133 \\
\hline $\begin{array}{l}\text { Institute of Business Administration (IBA), University of Dhaka(DU) } \\
\text { (Journal of Business Administration 41 papers, and Journal of Management } \\
\text { Business \& Economics 4 papers) }\end{array}$ & 1975 & 45 \\
\hline The Institute of Bankers, Bangladesh (IBB) & 1975 & 37 \\
\hline Bangladesh Institute of Bank Management (BIBM) & 1976 & 105 \\
\hline Department of Finance. University of Dhaka (DU) & 1979 & 10 \\
\hline Business faculty, University of Dhaka(DU) & 1979 & 84 \\
\hline Department of Economics, Jahangirnagar University (JU) & 1983 & 4 \\
\hline Business faculty, Rajshahi University (RU) & 1993 & 12 \\
\hline Business School, Khulna University (KU) & 1994 & 11 \\
\hline Department of Business Administration, Jahangirnagar University (JU) & 1998 & 17 \\
\hline Faculty of Social Science, Jahangirnagar University (JU) & 2000 & 2 \\
\hline Bangladesh Open University (BOU) & 2001 & 25 \\
\hline American International University Bangladesh (AIUB) & 2003 & 6 \\
\hline South East University (SEU) & 2005 & 2 \\
\hline Faculty of Business and Economics, Daffodil International University (DIU & 2006 & 1 \\
\hline School of Business, North South University (NSU) & 2006 & 2 \\
\hline Total & & 549 \\
\hline
\end{tabular}

Table 3: Year wise number of finance relevant publications

\begin{tabular}{|c|c|c|c|c|c|}
\hline Year & No. of Paper ${ }^{\wedge}$ & Year & No. of Paper ${ }^{\wedge}$ & Year & No. of Paper ${ }^{\wedge}$ \\
\hline
\end{tabular}




\begin{tabular}{|c|c|c|c|c|c|}
\hline 1977 & $5^{*}$ & 1987 & 8 & 1997 & 18 \\
\hline 1978 & 7 & 1988 & 18 & 1998 & 22 \\
\hline 1979 & 8 & 1989 & 12 & 1999 & 18 \\
\hline 1980 & 12 & 1990 & 12 & 2000 & 20 \\
\hline 1981 & 5 & 1991 & 16 & 2001 & 24 \\
\hline 1982 & 11 & 1992 & 15 & 2002 & 30 \\
\hline 1983 & 15 & 1993 & 14 & 2003 & 40 \\
\hline 1984 & 12 & 1994 & 18 & 2004 & 39 \\
\hline 1985 & 9 & 1995 & 21 & 2005 & 40 \\
\hline 1986 & 14 & 1996 & 21 & 2006 & 45 \\
\hline Total & 98 & Total & 155 & Total & 296 \\
\hline
\end{tabular}

* There was no relevant publication up to 1975; 3 papers published in 1976 are included here

$\wedge$ Total number of publications in any particular year may shift to/ from another year due to publishing several volumes/issues together as well as late publications. We leave the issue - to draw a concrete line and proper counting - for future researchers

Table 4: Period wise trends of research (number of publications) in the field of finance in Bangladesh

\begin{tabular}{|l|c|c|c|c|}
\hline \multicolumn{1}{|c|}{ Area } & $\begin{array}{c}\text { Early Trends } \\
(1976-1986)\end{array}$ & $\begin{array}{c}\text { Intermediate Trends } \\
(1987-1996)\end{array}$ & $\begin{array}{c}\text { Modern Trends } \\
(1997-2006)\end{array}$ & Total \\
\hline Banking & 30 & 50 & 89 & 169 \\
\hline Capital Market & 5 & 21 & 68 & 94 \\
\hline Corporate Finance & 11 & 12 & 38 & 61 \\
\hline Dividend Policy and Decision & 0 & 1 & 7 & 8 \\
\hline Financial Planning \& Analysis & 17 & 20 & 19 & 56 \\
\hline Financing and Capital Structure & 7 & 18 & 27 & 52 \\
\hline Insurance \& Risk Management & 1 & 5 & 16 & 22 \\
\hline Investment Decision and Analysis & 13 & 7 & 10 & 30 \\
\hline Money Market & 1 & 1 & 3 & 5 \\
\hline Valuation \& Pricing Theories & 0 & 6 & 10 & 16 \\
\hline Working Capital Management & 13 & 13 & 7 & 33 \\
\hline Miscellaneous & 0 & 1 & 2 & 3 \\
\hline Total Papers & 98 & 155 & 296 & 549 \\
\hline
\end{tabular}

Table 5: Number of published researches in the finance relevant areas and sub-areas

\begin{tabular}{cclcc}
\hline Sl. & Area & Sub Area & $\begin{array}{c}\text { No. of } \\
\text { Publication }\end{array}$ & Total \\
\hline \multirow{2}{*}{1} & \multirow{2}{*}{ Banking } & Agriculture & 8 & 169 \\
& & Bank Management & 1 & \\
\hline
\end{tabular}




\begin{tabular}{|c|c|c|c|c|}
\hline & & Deposits & 3 & \\
\hline & & Development & 4 & \\
\hline & & E-Banking & 1 & \\
\hline & & Ethics & 1 & \\
\hline & & Exchange Rate & 2 & \\
\hline & & Financial Reporting & 3 & \\
\hline & & Financial Sector Reform & 15 & \\
\hline & & Interest Rate & 4 & \\
\hline & & Loan \& Credit & 35 & \\
\hline & & Monetary Policy & 6 & \\
\hline & & Money Laundering & 2 & \\
\hline & & Performance Evaluation & 53 & \\
\hline & & Banking Policies & 13 & \\
\hline & & Regulatory and Framework & 4 & \\
\hline & & Role of Banks & 12 & \\
\hline & & Savings & 2 & \\
\hline \multirow{25}{*}{2} & \multirow{25}{*}{$\begin{array}{l}\text { Capital } \\
\text { Market }\end{array}$} & Behavioral Finance & 3 & \multirow{25}{*}{94} \\
\hline & & Book Building System & 1 & \\
\hline & & Capital Market Anomalies & 2 & \\
\hline & & Central Depository System & 1 & \\
\hline & & Challenge and Prospects & 2 & \\
\hline & & Debt Market & 2 & \\
\hline & & Earnings & 2 & \\
\hline & & Financial Market & 4 & \\
\hline & & Government Regulation & 2 & \\
\hline & & Growth Pattern & 2 & \\
\hline & & Initial Public Offering & 8 & \\
\hline & & Market Behavior & 5 & \\
\hline & & Market Development & 20 & \\
\hline & & Market Efficiency & 9 & \\
\hline & & Mutual Funds & 1 & \\
\hline & & Price Behavior & 3 & \\
\hline & & Problems \& Prospects & 2 & \\
\hline & & Returns & 2 & \\
\hline & & Seasonal Equity & 2 & \\
\hline & & Securities & 2 & \\
\hline & & Share Valuation/Price & 7 & \\
\hline & & Stock Index & 8 & \\
\hline & & Stock Return & 1 & \\
\hline & & Volatility of Price & 2 & \\
\hline & & Wealth Management & 1 & \\
\hline \multirow{4}{*}{3} & \multirow{4}{*}{$\begin{array}{l}\text { Corporate } \\
\text { Finance }\end{array}$} & Accounting Practices & 3 & \multirow{4}{*}{61} \\
\hline & & Acquisition/Merger & 1 & \\
\hline & & Corporate Earnings & 1 & \\
\hline & & Corporate Environment & 4 & \\
\hline
\end{tabular}




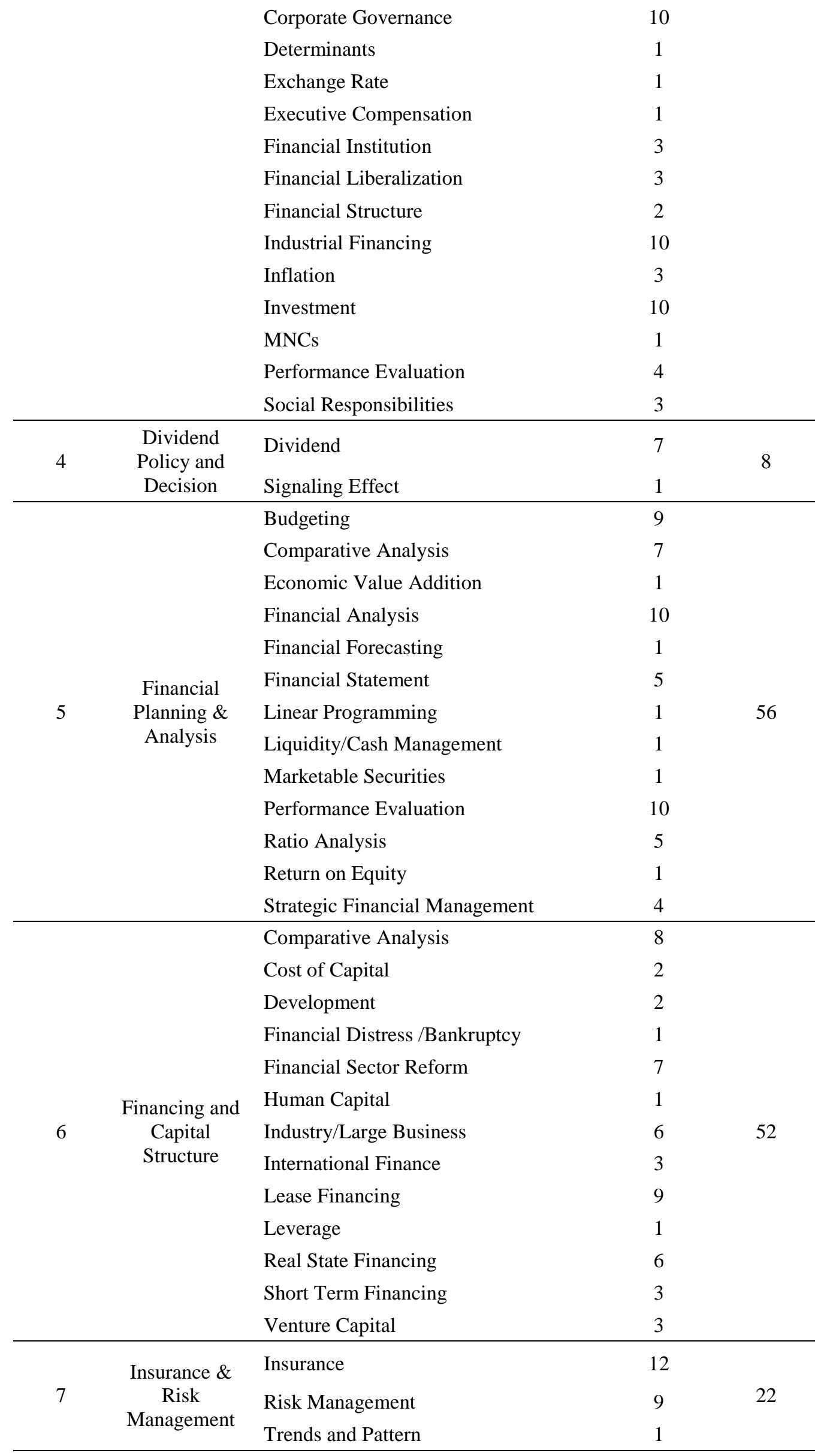




\begin{tabular}{|c|c|c|c|c|}
\hline \multirow{7}{*}{8} & \multirow{7}{*}{$\begin{array}{l}\text { Investment } \\
\text { Decision and } \\
\text { Analysis }\end{array}$} & Capital Budgeting & 7 & \multirow{7}{*}{30} \\
\hline & & Capital Investment & 9 & \\
\hline & & Depreciation & 1 & \\
\hline & & Interest Rate & 2 & \\
\hline & & Portfolio Management & 8 & \\
\hline & & $\begin{array}{l}\text { Symmetric and Asymmetric } \\
\text { Information }\end{array}$ & 2 & \\
\hline & & Tax & 1 & \\
\hline \multirow{3}{*}{9} & \multirow{3}{*}{$\begin{array}{l}\text { Money } \\
\text { Market }\end{array}$} & Call Money Rate & 1 & \multirow{3}{*}{5} \\
\hline & & Instruments & 2 & \\
\hline & & Market & 2 & \\
\hline \multirow{8}{*}{10} & \multirow{8}{*}{$\begin{array}{l}\text { Valuation \& } \\
\text { Pricing } \\
\text { Theories }\end{array}$} & CAPM & 6 & \multirow{8}{*}{16} \\
\hline & & Comparative analysis & 2 & \\
\hline & & Cost of Capital & 1 & \\
\hline & & Determinant & 1 & \\
\hline & & Gordon Model & 1 & \\
\hline & & Return on Investment & 2 & \\
\hline & & Risk Measurement & 2 & \\
\hline & & Stock Pricing & 1 & \\
\hline \multirow{6}{*}{11} & \multirow{6}{*}{$\begin{array}{c}\text { Working } \\
\text { Capital } \\
\text { Management }\end{array}$} & Cash Flow Estimation & 3 & \multirow{6}{*}{33} \\
\hline & & Inventory Management & 9 & \\
\hline & & Liquidity/Cash Management & 7 & \\
\hline & & Miller Theorem & 1 & \\
\hline & & Receivables & 1 & \\
\hline & & Theory \& Practice & 12 & \\
\hline \multirow{2}{*}{12} & \multirow{2}{*}{ Miscellaneous } & Non-Financial Factor & 1 & \multirow{2}{*}{3} \\
\hline & & Purchasing Power Parity & 2 & \\
\hline
\end{tabular}

